\title{
Housing and the Business Cycle
}

\author{
Morris Davis \\ Federal Reserve Board \\ Jonathan Heathcote* \\ Georgetown University
}

November 1, 2003

\begin{abstract}
In the United States, the percentage standard deviation of residential investment is more than twice that of non-residential investment. In addition, GDP, consumption, and both types of investment co-move positively. We reproduce these facts in a calibrated multi-sector growth model where construction, manufacturing and services are combined, in different proportions, to produce consumption, business investment and residential structures. New housing requires land in addition to new structures. The model can also account for important features of industry-level data. In particular, hours and output in all industries are positively correlated, and are most volatile in construction.
\end{abstract}

Keywords: Residential investment; Co-movement; Home production; Multisector models

\footnotetext{
${ }^{*}$ Corresponding author: Georgetown University, Department of Economics, ICC Building 5th Floor, Washington DC 20057. Email: jhh9@georgetown.edu. We thank three anonymous referees and the Editor for thoughtful comments and suggestions. Heathcote thanks the Economics Program of the National Science Foundation for financial support. The opinions expressed here are not necessarily those of the Board of Governors of the Federal Reserve System or its staff.
} 


\section{Introduction}

Although housing is typically considered part of the economy's capital stock in onesector models (see, for example, Cooley and Prescott 1995), there are good reasons for distinguishing between housing on the one hand and non-residential structures and equipment on the other. First, these different durable assets are produced using different technologies. Second, they have different uses: to the extent that housing is used for production, it is for production at home that for the most part is not marketed and not measured in national accounts.

Models that incorporate heterogeneous capital goods and in which business cycles are driven by technology shocks have had trouble accounting for three sets of facts. First, different sectors of the economy tend to move together, and in particular investment in different assets (such as residential structures and business capital) is positively correlated. Second, residential investment is more than twice as volatile as business investment. Third, residential investment leads the business cycle whereas non-residential investment lags.

The goal of this paper is to build a neoclassical multi-sector stochastic growth model to help us understand the dynamics of residential investment. In our model economy there are two final-goods sectors. One produces the consumption / business investment good, while the second produces residential structures which are combined with newly-available land to produce houses. Final goods firms use three intermediate inputs produced in the construction, manufacturing and services sectors. These intermediate inputs are in turn produced using capital and labor rented from a representative household. Productivity is stochastic as a result of exogenous sector-specific labor-augmenting technology shocks. A representative household maximizes expected discounted utility over per-capita consumption, housing services and leisure. Each period it decides how much to work and consume, and how to divide savings between physical capital and housing, both of which are perfectly divisible.

One attractive feature of the model's production structure is that data are available on the empirical counterpart to each variable in the model. ${ }^{1}$ Thus the model can be calibrated using aggregate data, industry-level data, and input-output tables from the

\footnotetext{
${ }^{1}$ This is not the case in the home production literature in which inputs to and productivity within the home sector are imperfectly observed.
} 
National Income and Product Accounts.

\section{Findings}

In terms of the trinity of puzzles outlined at the start of the introduction, our calibrated model succeeds on two counts out of three: (1) the percentage standard deviation of residential investment (at business cycle frequencies) is twice that of non-residential investment, and (2) consumption, non-residential investment, residential investment and GDP all co-move positively. In addition, the model economy can account for the facts that hours worked and output are most volatile in the construction sector and least volatile in the services sector, and that hours worked and output in all intermediate sectors co-move positively. The model does not reproduce the observations that nonresidential investment lags GDP while residential investment leads GDP. House prices are procyclical in the model, as in the data, but the model does not account for all observed price volatility.

In the simplest multi-sector models, different sectors tend to co-move negatively, since there is a strong incentive to switch production between sectors in response to sector-specific productivity shocks. Even if shocks are perfectly correlated across sectors, positive co-movement is not guaranteed, since following a positive shock the increase in the expected future rental rate may make it optimal to increase output of new non-residential capital prior to expanding anywhere else. ${ }^{2}$ What ingredients in our calibration procedure allow us to generate positive co-movement, and at the same time to account for the relative volatilities of residential and non-residential investment? ${ }^{3}$

\footnotetext{
${ }^{2}$ Various fixes have been proposed to solve the co-movement problem. Fisher 1997 assumes a nonlinear function for transforming output into non-durable consumption goods, new consumer durables, and new physical capital. Since in the limit different goods must be produced in fixed proportions it is easy to see how this approach can resolve the co-movement problem. Baxter 1996 estimates a high correlation between productivity growth across sectors and also introduces sectoral adjustment costs for investment. Chang 2000 combines adjustment costs with substitutability between leisure time and durable goods; thus when households work more in periods of high productivity they also demand more durables. Gomme, Kydland and Rupert 2001 introduce time-to-build in the sector producing new market capital, which has a similar effect to introducing adjustment costs in that it dampens the investment boom in the capital-producing sector and allows investment to rise in all sectors simultaneously. Boldrin, Christiano and Fisher 2001 find that a combination of limited labor mobility across sectors and a habit in consumption can generate co-movement in hours worked across sectors.

${ }^{3}$ Fisher 1997 finds that none of his specifications make household investment more volatile than business investment. In Baxter's 1996 model, consumption of durables (which includes residential
} 
First, while our Solow residual estimates suggest only moderate co-movement in productivity shocks across intermediate goods sectors, co-movement in effective productivity across final goods sectors is amplified by the fact that both final goods sectors use all three intermediate inputs, albeit in different proportions. Second, the production of new housing requires suitable new land, which is relatively expensive during construction booms. We find that land acts like an adjustment cost for residential investment, reducing residential investment volatility, and increasing co-movement. Third, construction and hence residential investment are relatively labor-intensive. This increases the volatility of residential investment because following an increase in productivity less additional capital (which takes time to accumulate) is required to efficiently increase the scale of production in the construction sector. Fourth, the depreciation rate for housing is much slower than that for business capital. This increases the relative volatility of residential investment and increases co-movement, since it increases the incentive to concentrate production of new houses in periods of high productivity.

\section{Alternative approaches}

Our model is related to the home production literature (see, for example, Benhabib, Rogerson and Wright 1991, or Greenwood and Hercowitz 1991) in addition to the multi-sector growth literature that begins with Long and Plosser (1983). In the home production framework, home capital and non-market time are combined to produce a non-marketed consumption good. Greenwood, Rogerson and Wright (1995 p.161) show that this approach is closely related to our alternative in which the housing stock enters directly in the utility function. In particular, given (i) a Cobb-Douglas technology for producing the home good from capital and labor, and (ii) log-separable preferences over leisure, market consumption and home consumption, the home production model has a reduced form in which only market consumption, market hours and the stock of home capital enter the utility function. The benchmark calibration adopted by Greenwood and Hercowitz (1991) satisfies these functional-form restrictions, which suggests that our model is closely related to theirs. The main difference is that contrary to Greenwood and Hercowitz, we do not assume a single (market) production technology. In the results section we systematically compare and contrast the two economies.

investment) is too smooth and is less volatile than business fixed investment in either sector. For all but one of the parameterizations they consider, Gomme, Kydland and Rupert 2001 find market investment to be more volatile than home investment, contrary to the pattern in the data. 
Most previous home production and multi-sector real business cycle models (such as Baxter 1996 or Hornstein and Praschnik 1997) do not distinguish housing from other consumer durables. ${ }^{4}$ We focus squarely on housing in part because we want to address the dynamics of residential investment and house prices, and in part because there are important differences between housing and other durables. First, housing is an important component of wealth: the value of residential structures (excluding land) is similar to the combined value of private non-residential structures and equipment, similar to annual GDP, and three times as large as the total stock of all other consumer durables. Second, housing is a much better store of value than consumer durables since residential structures depreciate at a rate of only 1.6 percent per year, compared to 21.4 percent for other durables. Third, the technology for producing new houses is more land-intensive and more construction-intensive than the technology for producing consumer durables. We shall argue that these details of depreciation rates and production technologies are crucial in accounting for residential investment dynamics.

There is another strand of literature that considers the role of housing in incompletemarkets environments. These models typically either focus on steady states (see for example Platania and Schlagenhauf 2000 or Fernandez-Villaverde and Krueger 2002) or else abstract from the production side of the economy (see Diaz-Gimenez, Prescott, Fitzgerald and Alvarez 1992, Peterson 2003, and Ortalo-Magne and Rady 2001). While frictions such as poorly functioning rental and mortgage markets are likely important in accounting for cross-sectional issues (such as life-cycle consumption / savings patterns or heterogeneity in asset holding portfolio choices) it is not obvious that they are important for housing dynamics at the aggregate level. ${ }^{5}$ In any case it would appear to be sensible to ask whether a representative agent model with complete asset markets is broadly able to capture observed aggregate dynamics before turning to richer environments.

\footnotetext{
${ }^{4}$ One exception is an exploratory paper by Storesletten 1993 who found that the process for sectorspecific shocks cannot account for the fact that residential investment leads the cycle. In a recent paper, Edge 2000 considers the differential effects of monetary shocks on residential and structures investment in a multi-sector model with sticky prices.

${ }^{5}$ Krusell and Smith 1998 and Rios-Rull 1994 study the aggregate dynamics of economies in which households face large amounts of uninsurable idiosyncratic risk. They find that they are virtually identical to those observed when markets are complete.
} 


\section{The Model}

The population grows at a constant gross growth rate $\eta$. In what follows all variables are in per-capita terms.

A representative household supplies homogenous labor and rents homogenous capital to perfectly competitive intermediate-goods-producing firms. These firms allocate capital and labor frictionlessly across three different technologies. Each technology produces a different good which we identify as construction, manufactures and services, and which we index by the subscripts $b, m$ and $s$ respectively. The quantities of each intermediate good produced at date $t$ are denoted $x_{i t}, i \in\{b, m, s\}$. Output of intermediate good $i$ is a Cobb-Douglas function of the quantity of capital $k_{i t}$ and labor $n_{i t}$ allocated to technology $i$ :

$$
x_{i t}=k_{i t}{ }^{\theta_{i}}\left(z_{i t} n_{i t}\right)^{1-\theta_{i}} .
$$

Note that the three production technologies differ in two respects. First, the shares of output claimed by capital and labor, determined by capital's share $\theta_{i}$, differ across sectors. For example, our calibration will impose $\theta_{b}<\theta_{m}$, reflecting the fact that construction is less capital-intensive than manufacturing. Second, each sector is subject to exogenous sector-specific labor-augmenting productivity shocks. We let $z_{i t}$ denote productivity in sector $i$ at date $t$.

Let $p_{i t}$ denote the price of good $i$ in units of the final consumption good. Let $w_{t}$ and $r_{t}$ be the wage and rental rate on capital measured in the same units. The intermediate firms' static maximization problem at date $t$ is

$$
\max _{\left\{k_{i t}, n_{i t}\right\}_{i \in\{b, m, s\}}} \sum_{i}\left\{p_{i t} x_{i t}\right\}-r_{t} k_{t}-w_{t} n_{t}
$$

subject to eq. 2.1 and to the constraints

$$
\begin{aligned}
& k_{b t}+k_{m t}+k_{s t} \leq k_{t}, \\
& n_{b t}+n_{m t}+n_{s t} \leq n_{t}, \\
& \left\{k_{i t}, n_{i t}\right\}_{i \in\{b, m, s\}} \geq 0 .
\end{aligned}
$$

The law of motion for intermediate firms' productivities has a deterministic and a stochastic component. We assume a constant trend growth rate for productivity in a given sector, but permit the rate to vary across sectors. Let $g_{z i}$ denote the constant 
gross trend growth rate of productivity associated with technology $i$. The stochastic component of productivity shocks follows an autoregressive process:

$$
\begin{aligned}
\tilde{z}_{t+1} & =\left(\log \widetilde{z}_{b, t+1}, \quad \log \widetilde{z}_{m, t+1}, \quad \log \widetilde{z}_{m, t+1}\right)^{\prime} \\
& =B \widetilde{z}_{t}+\varepsilon_{t+1} .
\end{aligned}
$$

Tildes are used to indicate that each element of $\tilde{z}_{t}$ records the deviation from trend value at $t$. For example,

$$
\log \widetilde{z}_{b t}=\log z_{b t}-t \log g_{z b}-\log z_{b 0} .
$$

The $3 \times 3$ matrix $B$ captures the predictable aspect of how shocks are transmitted through time, and $\varepsilon_{t+1}$ is a $3 \times 1$ vector of shocks drawn independently through time from a multivariate normal distribution with mean zero and variance-covariance matrix $V$.

The goods produced by intermediate goods firms are used as inputs by firms producing two final goods: a consumption / capital investment good and a residential investment good. Final goods firms are perfectly competitive and allocate the intermediate goods freely across two Cobb-Douglas technologies. We use the subscript $c$ to index the consumption / capital investment good and $d$ to index residential investment (RESI). Let $y_{j t}, j \in\{c, d\}$ denote the quantity of final good $j$ produced at $t$ using quantities $b_{j t}, m_{j t}$ and $s_{j t}$ of the three intermediate inputs. Thus

$$
y_{j t}=b_{j t}^{B_{j}} m_{j t}^{M_{j}} s_{j t}^{S_{j}} \quad j \in\{c, d\}
$$

where $B_{j}, M_{j}$ and $S_{j}=1-B_{j}-M_{j}$ denote the shares of construction, manufactures and services respectively in sector $j$. The technology used to produce the consumption good differs from that used to produce RESI with respect to the relative shares of the three intermediate inputs,. Thus, for example, our calibration leads us to set $B_{d}>B_{c}$, reflecting the fact that residential structures are relatively construction-intensive.

We normalize the price of the consumption good after any history to 1 , and let $p_{d t}$ denote the price of RESI. The final goods firms' static profit maximization problem at $t$ is 


$$
\max _{\left\{b_{j t}, m_{j t}, s_{j t}\right\}_{j \in\{c, d\}}}\left\{y_{c t}+p_{d t} y_{d t}-p_{b t}\left[b_{c t}+b_{d t}\right]-p_{m t}\left[m_{c t}+m_{d t}\right]-p_{s t}\left[s_{c t}+s_{d t}\right]\right\}
$$

subject to eq. 2.2 and

$$
\left\{b_{j t}, m_{j t}, s_{j t}\right\}_{j \in\{c, d\}} \geq 0 .
$$

There is a government which raises revenue by taxing labor income at a constant rate $\tau_{n}$ and capital income (less a depreciation allowance) at rate $\tau_{k} .{ }^{6}$ Tax revenues are divided between non-valued government spending on the consumption / investment good denoted $g_{t}$, and lump-sum transfers to households denoted $\xi_{t}$. Government consumption is assumed to be a constant fraction of output of the consumption / investment sector.

Houses in the model are not quite the same thing as residential structures. In particular, residential investment must be combined with land to produce new houses. We do not model the details of the supply of land suitable for residential development. ${ }^{7}$ Rather we simply assume that a constant acreage of new land suitable for residential development is sold by the representative household each period. This acreage is normalized to one. Real estate developers combine new residential structures with newly-available land to produce new houses according to a Cobb-Douglas technology to solve the following static maximization problem:

$$
\max _{x_{l t}, x_{d t}}\left\{p_{h t} y_{h t}-p_{l t} x_{l t}-p_{d t} x_{d t}\right\}
$$

subject to

$$
y_{h t}=x_{l t}^{\phi} x_{d t}^{1-\phi} .
$$

Here $\phi$ denotes the share of land in the production of new homes, $p_{l t}$ and $x_{l t}$ are the price and quantity of land purchased, and $p_{d t}$ and $x_{d t}$ are the price and quantity of new structures purchased.

Once a structure has been combined with a plot of land to build a house, we assume that the structure gradually depreciates over time at rate $\delta_{s}$, while the dimensions of the plot remain unchanged. Newly-built houses are assumed to be ready for occupation the

\footnotetext{
${ }^{6}$ In an earlier version of the paper we experimented with stochastic tax rates. We found the quantitative impact of introducing this additional source of uncertainty to be small.

${ }^{7}$ New road construction, declining relative returns to agricultural use, and changes in zoning restrictions are presumably important factors.
} 
following period. Thus, in equilibrium, the total stock of housing that may be enjoyed is given $b^{8}$

$$
\begin{aligned}
\eta h_{t+1}= & \left.x_{d t}^{1-\phi} x_{l t}^{\phi}+\frac{1}{\eta}\left[\left(1-\delta_{s}\right) x_{d, t-1}\right]^{1-\phi} x_{l, t-1}^{\phi}+\frac{1}{\eta^{2}}\left[\left(1-\delta_{s}\right)^{2} x_{d, t-2}\right]^{1-\phi} x_{l, t-2}^{\phi} 2.4\right) \\
& +\ldots \\
= & x_{d t}^{1-\phi} x_{l t}^{\phi}+\left(1-\delta_{s}\right)^{1-\phi} h_{t}
\end{aligned}
$$

The stock of structures per se does not enter the representative household's utility function; the household cares only about the stock of effective housing. Since we can keep track of the rate at which the housing stock depreciates without knowing anything about the stock of structures, it is not necessary to keep track of structures as a state variable. ${ }^{9}$ Rather we can simply note that houses depreciate at a rate defined by

$$
1-\delta_{h}=\left(1-\delta_{s}\right)^{1-\phi}
$$

and abstract entirely from structures in the definition of the household's problem.

The representative household derives utility each period from per-capita household consumption $c_{t}$, from per-capita housing owned $h_{t}$, and from leisure. The size of the household grows at the gross population growth rate $\eta$. The amount of per-householdmember labor supplied plus leisure cannot exceed the period endowment of time, which is normalized to 1 . Period utility per household member at date $t$ is assumed to be given by

$$
U\left(c_{t}, h_{t},\left(1-n_{t}\right)\right)=\frac{\left(c_{t}^{\mu_{c}} h_{t}^{\mu_{h}}\left(1-n_{t}\right)^{1-\mu_{c}-\mu_{h}}\right)^{1-\sigma}}{1-\sigma}
$$

where $\mu_{c}$ and $\mu_{h}$ determine the relative weights in utility on consumption, housing and leisure. The Cobb-Douglas functional form is consistent with evidence that the share of time devoted to market work exhibits little trend over time, and with the fact that the fraction of household income spent on shelter remained roughly constant according to the Consumer Expenditure Survey between 1984 and 2001.

\footnotetext{
${ }^{8}$ The population growth rate $\eta$ multiplies variables dated $t+1$ because all variables are in per-capita terms.

${ }^{9}$ Note also that all firms solve static maximization problems, so they do not care about the stock of structures either.
} 
At date 0, the expected discounted sum of future period utilities for the representative household is given by

$$
E_{0} \sum_{t=0}^{\infty} \beta^{t} \eta^{t} U\left(c_{t}, h_{t},\left(1-n_{t}\right)\right)
$$

where $\beta<1$ is the discount factor. ${ }^{10}$ Note that the flow of utility that households receive from occupying housing they own will constitute an implicit rent that is untaxed.

Households divide income between consumption, spending on new capital that will be rented out next period, and spending on new housing that will be occupied next period and has price $p_{h t}$. The depreciation rate for capital is given by $\delta_{k}$, while houses depreciate at rate $\delta_{h}$. In addition to income from renting out capital and labor, the representative household also receives income from selling land to developers. Thus the household budget constraint is

$$
\begin{aligned}
c_{t}+\eta k_{t+1}+\eta p_{h t} h_{t+1}= & \left(1-\tau_{n}\right) w_{t} n_{t}+\left[1+\left(1-\tau_{k}\right)\left(r_{t}-\delta_{k}\right)\right] k_{t}+ \\
& \left(1-\delta_{h}\right) p_{h t} h_{t}+p_{l t} x_{l t}+\xi_{t} .
\end{aligned}
$$

The representative household chooses state-contingent values for consumption, hours, capital and housing for all $t \geq 0$ to maximize expected discounted utility (eq. 2.6) subject to a sequence of budget constraints (eq. 2.7) and a set of inequality constraints $c_{t}, n_{t}, h_{t}, k_{t} \geq 0$ and $n_{t} \leq 1 .{ }^{11}$ The household takes as given a complete set of statecontingent prices and transfers $p_{h t}, p_{l t}, r_{t}, w_{t}, \xi_{t}$, tax rates $\tau_{k}$ and $\tau_{n}$, a probability distribution over future possible states, and the initial stocks of capital and housing.

\footnotetext{
${ }^{10}$ Note that the household weights per-household-member utility by the size of the household. Given our calibration strategy, whether the household effectively discounts at rate $\beta$ or at rate $\beta \eta$ will only affect the equilibrium value for $\beta$; this choice will have no impact on the business cycle properties of the model.

${ }^{11}$ In principle the description of the state at date $t$ may include a complete description of the history of the economy up to $t$. In a recursive formulation of the household's problem, the state may be summarized by a vector $\left(z_{b t}, z_{m t}, z_{s t}, k_{t}, h_{t}\right)$. In order to economize on notation, variables in the text are indexed only by date and not, as they formally should be, by both date and state. In equilibrium, the date zero probabilities households assign to different future states must be consistent with the process for sectoral productivity shocks.
} 


\subsection{Definition of equilibrium}

An equilibrium is a set of prices and transfers $p_{i t, i \in\{b, m, s\}}, p_{h t}, p_{d t}, p_{l t}, r_{t}, w_{t}, \xi_{t}$ for all possible states and for all $t \geq 0$ such that when households solve their problems and firms profit maximize taking these prices as given all markets clear and the government's budget constraint is satisfied.

Market clearing for the consumption / investment good, for housing, for structures and for land imply that

$$
\begin{aligned}
c_{t}+\eta k_{t+1}+g_{t} & =y_{c t}+\left(1-\delta_{k}\right) k_{t}, \\
\eta h_{t+1} & =y_{h t}+\left(1-\delta_{h}\right) h_{t}, \\
x_{d t} & =y_{d t}, \\
x_{l t} & =1 .
\end{aligned}
$$

Market clearing for intermediate goods implies that

$$
\begin{aligned}
b_{c t}+b_{d t} & =x_{b t}, \\
m_{c t}+m_{d t} & =x_{m t}, \\
s_{c t}+s_{d t} & =x_{s t} .
\end{aligned}
$$

Market clearing for capital and labor implies that

$$
\begin{aligned}
k_{b t}+k_{m t}+k_{s t} & =k_{t}, \\
n_{b t}+n_{m t}+n_{s t} & =n_{t} .
\end{aligned}
$$

Since the government cannot issue debt, the government budget constraint is satisfied when

$$
\xi_{t}+g_{t}=\tau_{n} w_{t} n_{t}+\tau_{k}\left(r_{t}-\delta_{k}\right) k_{t}
$$

\subsection{Equilibrium prices}

The first order conditions for the intermediate goods firms' problem are as follows.

With respect to capital by sector

$$
r_{t}=p_{i t} \theta_{i} k_{i t}^{\left(\theta_{i}-1\right)}\left(z_{i t} n_{i t}\right)^{1-\theta_{i}} \quad i \in\{b, m, s\} .
$$


With respect to labor by sector

$$
w_{t}=z_{i t} p_{i t}\left(1-\theta_{i}\right) k_{i t}^{\theta_{i}}\left(z_{i t} n_{i t}\right)^{-\theta_{i}} \quad i \in\{b, m, s\} .
$$

The first order conditions for the final goods firms' problem are as follows.

With respect to construction goods, manufactures and services by sector

$$
\begin{aligned}
p_{b t} & =\frac{B_{c} y_{c t}}{b_{c t}}=\frac{B_{d} y_{d t} p_{d t}}{b_{d t}}, \\
p_{m t} & =\frac{M_{c} y_{c t}}{m_{c t}}=\frac{M_{d} y_{d t} p_{d t}}{m_{d t}}, \\
p_{s t} & =\frac{S_{c} y_{c t}}{s_{c t}}=\frac{S_{d} y_{d t} p_{d t}}{s_{d t}} .
\end{aligned}
$$

The first order conditions for the real estate developers are as follows.

With respect to new structures and land

$$
\begin{gathered}
p_{d t}=\frac{(1-\phi) p_{h t} y_{h t}}{x_{d t}}, \\
p_{l t}=\frac{\phi p_{h t} y_{h t}}{x_{l t}} .
\end{gathered}
$$

It is straightforward to show that all firms make zero profits in every state.

From eqs. 2.12 to 2.15 we derive the following expression for the price of residential investment

$$
\begin{aligned}
\log p_{d t}= & \left(B_{c}-B_{d}\right)\left(1-\theta_{b}\right) \log z_{b t}+\left(M_{c}-M_{d}\right)\left(1-\theta_{m}\right) \log z_{m t}+ \\
& \left(S_{c}-S_{d}\right)\left(1-\theta_{s}\right) \log z_{s t}+\kappa \\
& +\left[\left(B_{c}-B_{d}\right) \theta_{b}+\left(M_{c}-M_{d}\right) \theta_{m}+\left(S_{c}-S_{d}\right) \theta_{s}\right]\left(\log k_{m t}-\log n_{m t}\right)
\end{aligned}
$$

where $\kappa$ is a constant. This expression indicates that a positive productivity shock in sector $i$ tends to reduce the relative price of residential investment if residential investment is relatively intensive in input $i$. The size of the relative price change is increasing in the difference in factor intensities across the two final goods technologies, and is increasing in the labor intensity of sector $i .^{12}$

\footnotetext{
${ }^{12}$ To the extent that a productivity shock affects equilibrium sectoral capital-output ratios, there is a second effect on the relative price of residential investment via the last term in eq. 2.18. This last effect disappears if $\theta_{b}=\theta_{m}=\theta_{s}$.
} 
From eq. 2.16 it is clear that the price of new housing is related to the price of residential investment. Substituting eq. 2.3 into eq. 2.16 and setting $x_{l t}=1$ gives

$$
\log p_{h t}=-\log (1-\phi)+\phi \log y_{d t}+\log p_{d t}
$$

Thus when land's share is zero, $p_{h t}=p_{d t}$. When land's share is positive, house prices are increasing in the price of structures, and increasing in the quantity of new structures produced. The intuition for the second effect is as follows. When more new structures are being produced, each new structure must be crammed onto a smaller lot. This reduces the quantity of housing services delivered by a given-size structure, so bigger (and more expensive) structures are required to produce an effective unit of housing services.

\subsection{Rental markets, mortgage markets, and house prices}

In the description of the model economy above we abstract from many aspects of housing that have attracted attention, such as the existence of rental markets, the market for mortgages, and the deductibility of mortgage interest payments. Markets in our model are complete, however, so it is straightforward to imagine rental or mortgage markets, and to price whatever is traded in these markets.

For example, one could imagine that each household rents out some or all of the housing it owns to its neighbor, thereby breaking the link between ownership and occupation and establishing a rental market. Given equilibrium allocations (which are independent of the size of this hypothetical rental market) the rental rate for housing, denoted $q_{t}$, is such that households are indifferent to renting a marginal unit of housing:

$$
q_{t}=\frac{U_{h}\left(c_{t}, h_{t},\left(1-n_{t}\right)\right)}{U_{c}\left(c_{t}, h_{t},\left(1-n_{t}\right)\right)}
$$

If rental income is taxed at a positive rate, households will strictly prefer owneroccupation to owner-renting since the implicit rents from owner-occupation are untaxed. If rental income is not taxed, the size of the rental sector is indeterminate.

Suppose next that rather than buying housing out of income, households have the option of borrowing on a mortgage market, where interest payments on these loans are tax deductible. It is straightforward to see that if the rate at which households can deduct mortgage interest payments against tax is exactly equal to the tax rate 
on capital income, then households will be indifferent between paying cash for housing versus taking out a mortgage. If the rate at which households can deduct mortgage interest is less than this, households strictly prefer to pay cash. The intuition is simply that the equilibrium net after-tax rate of interest on a mortgage loan in the economy is $\left(r_{t}-\delta_{k}\right)\left(1-\tau^{*}\right)$ where $\tau^{*}$ is the fraction of interest payments that may be deducted against tax. The marginal benefit of taking out a mortgage loan is the return on the extra dollar of savings that can then be saved, with return $\left(r_{t}-\delta_{k}\right)\left(1-\tau_{k}\right)$. Only if $\tau^{*}=\tau_{k}$ will households be indifferent between alternative ways of financing house purchases. ${ }^{13}$

We choose to define private consumption and GDP consistently with the National Income and Product Accounts. NIPA private consumption includes an imputed value for rents from owner-occupied housing. Thus private consumption expenditures is given by

$$
P C E_{t}=c_{t}+q_{t} h_{t}
$$

In our model the only productive use for land is in building new homes, so the supply of land as a factor of production is effectively increasing over time. The cost of raw land is not considered part of GDP in the NIPA. For consistency with the NIPA, we therefore include the value of residential investment in GDP rather than the value of new houses built. Thus GDP is given by

$$
G D P_{t}=y_{c t}+p_{d t} y_{d t}+q_{t} h_{t}
$$

Note lastly that during a simulation of the economy, prices are changing, both because of sector-specific trends in productivity and because of sector-specific shocks around these trends. We define real private consumption and real GDP using balanced growth path prices, so that our measures of real quantities capture trends in relative prices, but not short-run changes in relative prices.

\subsection{Solution method}

Our goal is to simulate a calibrated version of the model economy. The first step towards characterizing equilibrium dynamics is to solve for the model's balanced growth path. We have a multi-sector model in which the trend growth rate of productivity varies across

\footnotetext{
${ }^{13}$ Gervais 2002 conducts a richer analysis of the interaction between housing and the tax code.
} 
sectors. A balanced growth path exists since preferences and all production functions have a Cobb-Douglas form. The gross trend growth rates of different variables are described in table 1.

Several properties of these growth rates may be noted. The trend growth rates of $y_{c}$, $p_{h} y_{h}, p_{d} y_{d}, p_{l}$, and $p_{i} x_{i}$ for $i \in\{b, m, s\}$ are all equal to $g_{k}$, the trend growth rate of the capital stock and consumption. This growth rate is a weighted product of productivity growth in the three intermediate goods sectors. For example, if capital's share is the same across sectors then $g_{k}=g_{z b}^{B_{c}} g_{z m}^{M_{c}} g_{z s}^{S_{c}}$. The trend growth rates of intermediate goods prices exactly offset the effects of differences in productivity growth across sectors such that (i) interest rates are trendless in all sectors (see eq. 2.11) and (ii) wages in units of consumption grow at the same rates across sectors (see eq. 2.12).

Given trend growth rates for variables, the next step is to use these growth rates to take transformations of all the variables in the economy such that the transformed variables exhibit no trends. We do this because for computational purposes it is convenient to work with stationary variables. The new stationary variables are defined as follows, where $x$ denotes a generic old variable, $g_{x}$ is the gross trend growth rate of the variable, and $\hat{x}_{t}$ is the stationary transformation:

$$
\hat{x}_{t}=\frac{x_{t}}{g_{x}^{t}}
$$

The penultimate step in the solution method is to linearize a set of equations in stationary variables that jointly characterize equilibrium around the balanced growth path, which corresponds to a vector containing the mean values of the transformed variables in the system. We solve the system of linear difference equations using a Generalized Schur decomposition (see Klein 2000).

\subsection{Data and calibration}

The model period is one year. ${ }^{14}$ This is designed to approximately capture the length of time between starting to plan new investment and the resulting increase in the capital stock being in place. ${ }^{15}$ Edge (2000) reports that for non-residential structures the

\footnotetext{
${ }^{14}$ For more detail on data sources see the Data Sources Appendix at the end of this paper. Additional data and details of calibration procedures are available in "Housing and the Business Cycle: Data Appendix" which is available at http://morris.marginalq.com/

${ }^{15} \mathrm{~A}$ yearly model is also convenient because data on inputs and output by intermediate industry are only available on an annual basis. In the first draft of this paper, however, we set the period length to a
} 
average time to plan is around 6 months, while time to build from commencement of construction to completion is around 14 months. For residential investment the corresponding figures are 3 months and 7 months. ${ }^{16}$

Parameter values are reported in tables 2 and 3 . The population growth rate is set to 1.67 percent per year, the average rate of growth of hours worked in the private sector between 1948 and 2001, which is the sample period used for calibration purposes. Data from the National Income and Product Accounts (NIPA) tables, the Fixed Reproducible Tangible Wealth tables, the Gross Product by Industry tables, and the Benchmark Input-Output Accounts of the United States, 1992 (all published by the Department of Commerce) are used to calibrate most remaining model parameters. Data on house prices are taken from the Freddie Mac Conventional Mortgage Home Price Index. ${ }^{17}$ To calculate the relative price of houses, we divide this price index by the NIPA price index for Personal Consumption Expenditure.

The empirical analogue of the model capital stock is the stock of private fixed capital (excluding the stocks of residential capital and consumer durables) plus the stock of government non-defense capital. The depreciation rate for capital, $\delta_{k}$, is set to 5.57 percent, which is the average annual depreciation rate for appropriately measured capital between 1948 and 2001. The share of raw land in new houses, $\phi$, is set to 0.106 following an unpublished estimate from the Census Bureau. ${ }^{18}$ The average annual depreciation

quarter, and used an interpolation procedure to estimate sector-specific shocks. Business cycle statistics are substantively the same for both period lengths.

${ }^{16}$ Gomme, Kydland and Rupert 2001 argue that the faster time to build for residential structures can help account for the fact that non-residential investment lags the cycle, and that residential and non-residential investment are positively correlated contemporaneously. In their calibration they set the time to build for residential investment to 1 quarter, and the time for non-residential investment to 4 quarters. This difference is probably too large, both because time to build for residential investment is likely longer than a quarter, and also because private non-residential structures only accounts for $27 \%$ of total non-residential investment over the sample period; the majority of non-residential investment is accounted for by investment in equipment and software which can presumably be put in place more quickly. While there may still be a role for differential time to build, we abstract from it in this analysis to examine alternative mechanisms for generating realistic dynamics for investment over the business cycle.

${ }^{17}$ This price index is constructed using data on repeat sales, which helps control for changes over time in house quality.

${ }^{18}$ The Census Bureau uses this estimate to infer value-put-in-place from new home sales data, so it is consistent with the way the residential investment series in the National Income and Product Accounts 
rate for residential structures is $\delta_{s}=1.57$ percent which, given eq. 2.5 implies $\delta_{h}=1.41$ percent.

The coefficient of relative risk aversion, $\sigma$, is set equal to 2. All other preference parameters are endogenous. The shares of consumption and housing in utility $\left(\mu_{c}\right.$ and $\left.\mu_{h}\right)$ are chosen so that in steady state, households spend 30 percent of their time endowment working, and so that the value of the stock of residential structures is equal to annual GDP, which is the case, on average, for the sample period. On the balanced growth path, it is possible to show that the ratio of the value of the stock of residential structures, $p_{d} s$, (measured at the current price of structures) to the value of the stock of housing is the following constant:

$$
\frac{p_{d} s}{p_{h} h}=\frac{g_{h}(1-\phi)}{g_{d}}\left[\frac{1-\lambda^{1-\phi}}{1-\lambda}\right]
$$

where $\lambda=\frac{1-\delta_{s}}{g_{d} \eta}, g_{h}$ and $g_{d}$ denote the balanced growth path growth rates for the stock of housing and the stock of structures (see table 1 ) and $s$ denotes the stock of structures. ${ }^{19}$ In equilibrium, given all the parameter values that appear in eq. 2.20, structures account for 79.9 percent of the value of the housing stock on the balanced growth path. ${ }^{20}$ Thus if the value of structures is equal to GDP, the housing stock in the model is 126 percent of the value of GDP. Note that in total, land accounts for 20.1 percent of the value of the housing stock, while it is only 10.6 percent of the value of new housing. Thus the model captures the fact that older houses tend to be more land-intensive than newer homes.

The discount factor, $\beta$, is set so that the annual after-tax real interest rate in the model is 6 percent. The implied value for $\beta$ in the benchmark model is 0.951 .

Industry-specific data (industries are defined according to the 1987 2-digit SIC) are used to calibrate capital shares for the three intermediate sectors of the model: construction $(b)$, manufacturing $(m)$, and services $(s)$. For the model construction sector, we use SIC construction industry data. For manufacturing, we use all NIPA is constructed. The 0.106 figure is from an unpublished 2000 memo from Dennis Duke to Paul L. Hsen entitled "Summary of the One-Family Construction Cost Study".

${ }^{19}$ Here all structures are valued at the price of new residential investment goods. The BEA price index for the stock of structures is nearly identical to the price index for new residential investment.

${ }^{20}$ The corresponding average value computed from Federal Reserve Flow of Funds data over the 1948 to 2001 period is 76.9 percent. 
classified "goods-producing" industries except construction: agriculture, forestry, and fishing (AFF), mining, and manufacturing. For services we use all "services-producing" industries except FIRE: transportation and public utilities, wholesale trade, retail trade, and services. ${ }^{21}$

For each model sector $i$, the sectoral capital share in year $t, \theta_{i, t}$, is defined as

$$
\theta_{i, t}=1-\frac{\sum_{j} C O M P_{j, t}}{\sum_{j}\left\{V A_{j, t}-I B T_{j, t}-P R O_{j, t}\right\}}
$$

where the $j$ subscript denotes the specific SIC industries included in sector $i$, and $C O M P_{j, t}, V A_{j, t}, I B T_{j, t}$ and $P R O_{j, t}$ denote, respectively, nominal compensation of employees, nominal value added, nominal indirect business tax and non-tax liabilities, and nominal proprietor's income for industry $j$ in year $t$. The average value of the capital share over the period is 0.132 for the construction sector, 0.309 for manufacturing, and 0.237 for services (see table 3 ).

The logarithm of the (non-stationary) annual Solow residual in intermediate sector $i$ is given by

$$
\log \left(z_{i t}\right)=\frac{1}{1-\theta_{i}}\left[\log \left(x_{i t}\right)-\theta_{i} \log \left(k_{i t}\right)-\left(1-\theta_{i}\right) \log \left(n_{i t}\right)\right] .
$$

where $x_{i t}$ is real output of intermediate sector $i$ in year $t, k_{i t}$ is real sectoral capital, and $n_{i t}$ is sectoral hours worked.

The residual of a regression of $\log \left(z_{i t}\right)$ on a constant and a time trend over the sample period defines the logarithm of the detrended annual Solow residual for industry $i$, denoted $\log \left(\widetilde{z}_{i t}\right)$. The annual growth rates of the non-stationary Solow residuals are -0.27 percent in construction, 2.85 percent in manufacturing, and 1.65 percent in services, identifying the annual growth rates $g_{z b}, g_{z m}$, and $g_{z s}{ }^{22}$

Government consumption is set equal to 17.9 percent of GDP, the period average. ${ }^{23}$ The constant tax rates on capital and labor income, $\tau_{k}$ and $\tau_{n}$, are set so that along

\footnotetext{
${ }^{21}$ The FIRE (finance, insurance, and real estate) industry is omitted when calculating the capital share of the service sector of the model because much of FIRE value added is imputed income from owner-occupied housing. Excluding FIRE has the effect of reducing capital's share in the service sector.

${ }^{22}$ The apparent lack of productivity growth in construction has long been a focus of debate; see, for example, Pieper 1990.

${ }^{23}$ Government consumption in the data is defined as NIPA government consumption expenditures plus NIPA government defense investment expenditure.
} 
the balanced growth path the model matches two features of the data over the period: the non-residential capital stock averages 1.517 times annual output, and government transfers average 7.6 percent of GDP.

In the model, logged detrended sectoral productivities are assumed to follow a joint autoregressive process. The estimates of the parameters defining this process are in table 4. A few features of these estimates are worth mentioning. First, there is little evidence that technology shocks spill-over across intermediate goods sectors. Second productivity shocks in the construction and manufacturing sectors appear to be considerably more volatile than those in services. Productivity shocks are weakly correlated across sectors, and in particular shocks to the construction sector are essentially uncorrelated with those in manufacturing.

An important part of the calibration procedure concerns the estimates for $\left\{B_{c}, M_{c}, S_{c}\right\}$ and $\left\{B_{d}, M_{d}, S_{d}\right\}$, the shares of construction, manufacturing and services in production of the consumption-investment good (subscript $c$ ) and the residential investment good (subscript $d$ ). These parameters determine the extent to which residential investment is produced with a different mix of inputs than other goods. At this point, we employ the "Use" table of the 1992 Benchmark NIPA Input-Output (IO) tables. The IO Use table contains two sub-tables. In the first, total spending on components of final aggregate expenditure (personal consumption, private fixed investment, etc.) is decomposed into sales purchased from all intermediate industries. In the second, total sales for each private industry (and for the government) are attributed to value-added by that industry, and sales purchased from other industries. Thus, for example, final sales of the construction industry include value added from construction and sales purchased from the manufacturing and services sectors.

One possible approach would be to assume that the distribution of value-added across intermediate sectors for each component of final demand is equal to the distribution of sales purchased from the different sectors (see table 5). Rather than doing this, we use the second IO table to track down where value was originally created in each intermediate industry's sales. For example, some portion of construction sales is attributed to purchases from manufacturing, which in turn can implicitly be divided into manufacturing value added plus sales to manufacturing from construction and services. Since this trail is never ending, dividing the final sales of a particular industry into fractions of value-added by each intermediate industry requires an infinite recursion. 
Once we have this breakdown, we use the first IO Use table to compute, for example, the fraction of value added in residential investment from the construction industry (which will identify the parameter $B_{d}$ ). The results are given in table 6 . The shares of value added by construction, manufacturing and services in the consumption-investment sector are respectively $B_{c}=0.0307, M_{c}=0.2696$, and $S_{c}=0.6998$. For residential investment, the corresponding shares are $B_{d}=0.4697, M_{d}=0.2382$, and $S_{d}=0.2921$. Comparing tables 5 and 6 it is clear that there are large differences between the distribution of value added and the distribution of sales. For example, although we attribute residential investment entirely to sales from construction, these construction sales implicitly contain large quantities of value originally created in the manufacturing and service industries, such that only 47 percent of the value of residential investment is ultimately attributable to the construction industry. ${ }^{24,25}$

Note that there are no explicit adjustment costs for putting either new capital or new housing in place. However, land will act similarly to an adjustment cost in new home construction. The reason is that the amount of new land that comes available is fixed, so there are diminishing returns to putting up more structures in a given period.

\subsection{Questions}

There are three sets of issues we use the model to address. First, we ask how successful is the calibration procedure in terms of matching first moments, such as the average fraction of GDP accounted for by residential investment. Second, we simulate the model and compare second moments of simulated model output to the data. This is the standard exercise in the real business cycle tradition. To gain some intuition about how the model works, we systematically consider several alternatives to our benchmark calibration, including one which corresponds to Greenwood and Hercowitz (1991). Third, we feed in the actual productivity shocks suggested by our calibration procedure, and examine the extent to which the model can account for the observed history of a set of macroeconomic aggregates from 1948 to 2001.

\footnotetext{
${ }^{24}$ More details concerning the matrix algebra used to construct table 6 are in "Housing and the Business Cycle: Data Appendix" at http://morris.marginalq.com/.

${ }^{25}$ Hornstein and Praschnik 1997 describe a model in which a non-durable intermediate input is used in durable goods production, but they do not use Input-Output data in their calibration procedure.
} 


\section{Results}

\subsection{First moments}

Table 7 indicates that the model is very successful in terms of matching first moments. For example, the shares along the balanced growth path of the various components of aggregate expenditure are virtually identical in the model and the data. In particular, note that the model reproduces the observed shares of non-residential and residential investment in GDP. These shares are sensitive to the depreciation rates for non-residential capital and residential structures, and to the growth rates for productivity and population. ${ }^{26}$ In terms of the shares of gross private domestic income accounted for by the three intermediate goods sectors, the calibration delivers the correct average size of the construction industry, but delivers a manufacturing share that is too small relative to the sample average in the data. The reason is that intermediate goods shares in final goods production were computed using the 1992 Input-Output tables, and manufacturing's share of the economy has declined over the post War period. ${ }^{27}$ The tax rates generated by the calibration procedure are $\tau_{k}=37.9$ percent, and $\tau_{n}=28.9$ percent. These are extremely close to standard estimates in the taxation literature (see, for example, Domeij and Heathcote 2003).

\subsection{Second moments}

We simulate our model economy to determine whether it is capable of accounting for some of the facts regarding the behavior of housing over the business cycle in the United States. A large set of business cycle moments are presented in table 8. We find that our benchmark model can account for many of the features of the data that we document in the introduction. In particular, the model approximately reproduces the volatilities of both non-residential investment and residential investment relative to GDP, and residential investment is positively correlated with consumption, non-residential investment and GDP. Thus the model can account for both the relative volatility and the

\footnotetext{
${ }^{26}$ Our 5.6 percent depreciation rate for capital is lower than some previous estimates. Note, however, that we exclude fast-depreciating consumer durables from our measure of the capital stock. In addition, we explicitly account for both productivity growth and population growth. For a given depreciation rate, both these features increase the investment rate along the model's balanced growth path.

${ }^{27}$ The empirical shares of manufacturing and services in 1992 GDP are 23.6 and 71.3 percent.
} 
co-movement puzzles. In addition we find that house prices are pro-cyclical. ${ }^{28}$ Labor supplies and outputs are correlated across intermediate goods sectors, and output and employment are most volatile in the construction industry and least volatile in the services industry.

There are, however, two respects in which the model performs poorly. First, house prices are more volatile than GDP in the U.S., while in the model they are less than half as volatile as GDP. Second, a striking feature of residential investment noted in the introduction is that it strongly leads the cycle; the correlation between GDP and residential investment the previous year is larger than the contemporaneous correlation between the two (see table 8). In the model the strongest correlation is the contemporaneous one, and thus the model fails to reproduce this feature of the data. ${ }^{29}$

\section{Comparison to Greenwood and Hercowitz (1991)}

To understand which features of the model allow us to reproduce particular features of the data, we consider several alternative parameterizations (see table 9).

Our first alternative parameterization is essentially the benchmark model in Greenwood and Hercowitz (1991). The model effectively has only one production technology, capital and housing depreciate at the same rate, and land is not a factor of production. Thus this set up is a standard one-sector RBC model, except that some fraction of the capital stock enters the utility function rather than the production function. Utility is log-separable in consumption, housing and leisure, and thus the model can be reinterpreted as a reduced form of an economy with home production (see the introduction). Simulation results are in column $G H$ of table 10. Since the different intermediate goods are produced using identical technologies and enter symmetrically in production of the two final goods, the model has nothing to say regarding the relative volatilities and cross-sectoral correlations of construction, manufacturing and services. In other respects the model performs poorly. For example, the model predicts no volatility in house prices, because there is never a productivity differential between production of

\footnotetext{
${ }^{28}$ House prices are weakly negatively correlated with residential investment in the model, while this correlation is weakly positive in the data. Increasing land's share in home building raises the model correlation; it becomes positive when land's share exceeds 0.17.

${ }^{29}$ The model can claim a more limited success, however, in that the correlation between residential investment at a lead of a year with GDP is larger than the correlation when residential investment is lagged by a year. Our paper does about as well in terms of replicating observed lead-lag patterns as Gomme et. al. 2001, who focus on differential time-to-build across sectors.
} 
consumption versus residential investment. Residential investment is much less volatile in the model than in the data.

For each of the other parameterizations we consider (columns $A$ through $F$ ), we set six preference and fiscal parameters $\left(\beta, \mu_{c}, \mu_{h}, g, \tau_{k}\right.$ and $\left.\tau_{n}\right)$ so that the balancedgrowth-path ratios to GDP of government spending, transfers, capital and housing are all equal to their calibration targets, so that labor supply is 30 percent of the time endowment, and so that the after tax interest rate is 6 percent. One way to think of this exercise is that for each alternative parameterization we recalibrate the model so that it does a reasonable job in terms of matching certain first moments of the data, and then simulate to assess how second moments vary across parameterizations.

\section{Non-permanent shocks}

The main differences between the $G H$ parameterization and the economy labeled $A$ in tables 9 and 10 is that the coefficient of relative risk aversion is increased to 2, (the value in our baseline calibration), and productivity shocks are stationary (but persistent) rather than unit root. In many respects these changes worsen the performance of the model. Non-residential investment is much more volatile than residential investment, and the two types of investment co-move negatively contemporaneously. Moreover, nonresidential investment strongly leads GDP, while residential investment strongly lags, exactly the opposite of what is observed in the data.

In terms of the model's business cycle properties, the key difference between the Greenwood Hercowitz calibration and economy $A$ is the persistence of the productivity shocks. ${ }^{30}$ Holding all other parameters constant but raising the persistence of the shocks in economy $A$ until they are permanent (as in Greenwood and Hercowitz) raises the correlation coefficient from -0.1 to 0.88 and lowers the volatilities of non-residential and residential investment to 2.02 and 1.55 respectively. Because shocks are more persistent in economy $G H$, consumption is more volatile and investment is less volatile than in economy $A$. This is a familiar result from the standard one-sector growth model. Since non-residential investment increases by less following a positive shock in economy $G H$ than in economy $A$, more resources are available to simultaneously increase residential investment, and the implied correlation between the two types of investment is positive.

\footnotetext{
${ }^{30}$ Note that the coefficient of risk aversion, $\sigma$, is equal to 2 in economy $A$, while Greenwood and Hercowitz assume $\sigma=1$. We find that this difference has a quantitatively minor impact on the business cycle properties of the model.
} 


\section{Land}

We now proceed to add increasing realism, layer by layer, to the straw-man models described above. The first thing we add is land, so that houses are now produced using newly available land in addition to new structures. Introducing land has a large effect on the behavior of the model (see column $B$ of table 10) even though land sales account for only around one percent of aggregate income (land is 10.6 percent of new home construction, and new home sales in turn are 10.3 percent of GDP in economy $B)$. In particular, the volatility of residential investment falls dramatically, and the two types of investment are now positively correlated. Effectively land works just like a traditional convex adjustment cost on residential investment, as is clear from equation 2.4. With new land in fixed supply, additional residential investment in a given period yields smaller and smaller increments to the effective housing stock and thereby drives up the price of new (and existing) houses. Thus introducing land reduces the volatility of residential investment, introduces volatility in house prices, and implies a positive residential investment / house price correlation.

There are still many respects, however, in which the gap between the model and the data remains large. One is the relative volatility puzzle; business investment is much more volatile than residential investment, contrary to the pattern in the data.

\section{Sector-specific shocks}

We next introduce sector-specific productivity shocks (see column $C$ ). The shock process used is described in the calibration section. Since productivity shocks are estimated to be more volatile in construction and manufacturing than services, this change has the effect of generating relatively more volatile output (and employment) in these sectors. However, since all final goods are still produced using the same technology, this change has little effect on the business cycle dynamics of any macro aggregates.

\section{A distinct production technology for residential structures}

Column $D$ introduces different final goods production technologies for the consumption / business investment versus the residential investment sectors. This change has large effects. Because intermediate input intensities now differ across the two different final goods, sector-specific productivity shocks change the effective relative cost of building new houses versus other goods. Households now have an incentive to specialize in accumulating whichever type of asset is relatively cheap, which reduces the correlation 
between residential and non-residential investment from 0.75 to -0.07 . The correlation would be even more negative were it not for the fact that positive correlation between the underlying productivity shocks to intermediate goods sectors is effectively magnified at the final goods level, since both final goods sectors use all three intermediate goods as inputs (albeit in different proportions).

Allowing for two final goods technologies more than triples the percentage standard deviation of residential investment, such that residential investment is now more volatile than non-residential investment. The explanation for this result hinges on the fact that construction is a much more important input for residential investment than for the rest of the economy. Recall that productivity shocks in the construction industry have a larger variance than those in the services industry. These characteristics of the construction technology tend to increase the relative volatility of construction-intensive residential investment. If the variance of shocks is (counter-factually) assumed equal across sectors, non-residential investment is much more volatile than non-residential investment.

There is an additional effect in the opposite direction, however, in that output and employment in the construction sector are now more volatile than in the equivalent version of the model with a single final goods sector (compare columns $C$ and $D$ ). With a separate residential investment sector, a fall in the relative price of construction inputs associated with an increase in construction productivity translates into a fall in the price of residential investment (see eq. 2.18). Since demand for residential investment is very price sensitive this in turn generates a large boom in residential investment and in the demand for construction inputs. Thus, part of the reason the construction industry is so volatile is that a large fraction of the demand for its output is for residential investment.

\section{Sector-specific capital shares}

The next feature we add is sector-specific capital shares for intermediate-goods firms (column $E$ ). The fact that construction is relatively labor-intensive means that output of the construction sector becomes more volatile than in the previous case, while the fact that manufacturing is relatively capital-intensive reduces the volatility of manufacturing output. The intuition is simply that following a good productivity shock, it is easier to expand output rapidly the more important is labor in production, since holding capital constant, the marginal product of labor declines more slowly. This in turn implies more volatile residential investment, since residential investment is relatively construction- 
intensive and thus relatively labor-intensive.

\section{Asset-specific depreciation rates}

Finally, in column $F$, our benchmark model, we introduce different depreciation rates for non-residential capital and residential structures. The largest effect of this change is to increase the volatility of residential investment, so that residential investment is now almost twice as volatile as non-residential investment. The reason reducing the depreciation rate for residential structures increases the volatility of residential investment is that slower depreciation increases opportunities to concentrate residential investment in periods of high productivity; conversely during a prolonged period of low productivity, it is possible to build few or no new homes without bringing about a large fall in the stock. Introducing a lower depreciation rate for residential structures also increases the correlation between residential and non-residential investment, and between residential investment and house prices. The reason is that when residential structures depreciate more slowly, residential investment is a smaller share of the economy (4.4 percent of GDP in the benchmark model versus 8.4 percent for the economy in column $E$ ), so booms in residential investment have less of a tendency to starve the rest of the economy of resources. ${ }^{31}$

\subsection{U.S. history}

The aim of this section of the paper is to compare the observed timepaths for a set of macro variables over the post-War period to those predicted by our model, given the estimated series of productivity shocks. In particular, we assume that the U.S. economy

\footnotetext{
${ }^{31}$ In results not reported, we also experimented with introducing stochastic tax rates on capital and labor. The main effects of this change are (i) to increase the volatility of labor supply (because temporary changes in the labor income tax rate change the relative returns to working at different dates), (ii) to increase the volatility of output (because hours are more volatile), and (iii) to increase the correlation between house prices and residential investment (because tax shocks can effectively shift the demand curve for new housing, inducing price and quantity to co-move). All these changes improve the overall success of the model in terms of replicating observed business cycle dynamics. In other respects the model with stochastic tax rates looks very similar to the benchmark model. We had expected that introducing stochastic capital income taxes would impact investment dynamics by increasing time variation in the relative expected after-tax returns to saving in the form of taxed capital versus untaxed housing. However, the effect on investment volatility turns out to be quantititatively small, in part because capital tax shocks are not very persistent.
} 
was on its balanced growth path until the start of 1949, and that from 1949 until 2001 the shocks that generated deviations from the balanced growth path were equal to the residuals generated from the autoregressive estimation procedure described in the calibration section. This is a more ambitious exercise than the simulation exercise conducted above in that we are now assessing the performance of the model at all frequencies. In particular, we shall address the extent to which the model can jointly account for observed long-run trends as well as business cycle fluctuations. Moreover, we look at sectoral output and house prices, in addition to the standard macro aggregates. The series in figures 1 and 2 are all scaled so that in both model and data the mean of each variable over the sample period is equal to one.

Across the sample period real U.S. private consumption and GDP both increased by approximately a factor of six. At the same time, non-residential investment increased by a factor of ten whereas residential investment grew less than half as much. The model does an excellent job of matching trend growth in hours worked, consumption and output. Since the focus of the paper is primarily on residential investment, it is reassuring that the model correctly predicts residential investment to be the slowest growing component of GDP. The reason is simply that since residential investment is construction intensive, and negative trend growth in construction productivity means that the relative prices of residential investment and of housing tend to be rising over time. This reduces growth in the demand for new housing; given Cobb-Douglas preferences expenditure shares on consumption, leisure and housing are constant along the balanced growth path.

The biggest failures of the model at low frequencies are in replicating the growth of non-residential investment and of manufacturing output. The model overpredicts manufacturing growth, since manufacturing's share of trend nominal output is constant in the model, whereas manufacturing's share of nominal output has fallen over the sample period. The fact that the model underpredicts growth in non-residential investment is likely in part a consequence of assuming a constant depreciation for capital; when we estimate depreciation rates using NIPA nominal depreciation figures, we find the rate of depreciation to be rising over time. A second reason the model underpredicts non-residential investment growth is that we assume a common production technology for consumption and business investment, whereas in reality non-residential investment is more manufacturing-intensive than consumption (see table 6). Thus the model gen- 
erates too little trend decline in the relative price of business capital (generated by manufacturing productivity growth) and too little real growth in business investment.

Consider next the ability of the model to account for U.S. macroeconomic history at business cycle frequencies. For various macro aggregates figure 3 describes percentage deviations from a Hodrick-Prescott trend with the smoothing parameter $\lambda$ set to 100. Note first that the model closely reproduces the histories of deviations from trend in GDP, consumption and both types of investment, suggesting that productivity shocks can largely account for observed cyclical dynamics. ${ }^{32}$ The model also does a good job in accounting for historical output fluctuations at the sectoral level (see figure 2). One caveat is that non-residential investment in the data appears to slightly lag non-residential investment in the model (which fits with the fact that non-residential investment lags the cycle empirically whereas the model delivers no strong lead-lag patterns). Comparing the last two major recessions, the model does a good in accounting for the depth of the recession in the early 1980's, including a dramatic fall in residential investment which was 38 percent below trend in 1982. However, the model somewhat underpredicts the depth of the recession in the early 1990's. ${ }^{33}$

One important respect in which the model performs poorly is in accounting for house price dynamics. The model does at least correctly predict an upward trend in the relative price of housing (see figure 2). The reason for the upward trend in the model is twofold. First, productivity in the construction industry has been declining over time relative to productivity in other industries. Second, the relative price of land is rising over time. In terms of cyclical volatility, the model does not account for a large fraction of observed house price dynamics, and in particular it fails to capture the three booms in house prices since 1970 .

\subsection{Relation to empirical literature on residential investment}

Lastly, we briefly contrast our model with the typical framework for thinking about residential investment. A simple version of the traditional model may be visualized as follows (see Kearl 1979, Topel and Rosen 1998, or Poterba 1984 and 1991). There is an upward-sloping supply curve for residential investment, since higher prices encourage

\footnotetext{
${ }^{32}$ The relatively poor fit in the first few years of the sample might be due to the U.S. economy being off its balanced growth path prior to 1949, contrary to the assumption made here.

${ }^{33}$ Hansen and Prescott 1993 also investigate the 1990-1991 recession in a multi-sector model.
} 
developers to build more houses. The demand curve for new houses is assumed to be infinitely elastic, since houses are viewed as financial assets that must pay the market rate of return. Demand shocks affect future expected rents (dividends on the housing asset) and shift the demand curve up and down. Thus equilibrium price / investment pairs are traced out along the residential investment supply curve. By contrast, in our model the dynamics of both residential investment and house prices are primarily driven by supply-side productivity shocks.

In empirical work, when residential investment is regressed on house prices and cost measures (such as the real interest rate), the coefficient on the house price term typically turns out to be positive and significant. This appears to confirm the traditional demand-shock driven view of residential investment. At the same time, a positive house price coefficient is prima facie inconsistent with a productivity shock driven theory of residential investment, according to which one might expect an increase in residential investment to be associated with higher relative productivity in the house-building sector and thus lower house prices.

In the model there are no demand-side shocks, such as shocks to the marginal utility of housing. Nonetheless, in simulated model output, a regression of residential investment on house prices and the interest rate yields a positive coefficient on house prices. This surprising result arises because this regression (in common with equations estimated in previous empirical work) is mis-specified relative to the structural equilibrium relationships implied by the model. Performing a correctly-specified regression on simulated data requires adding as an additional regressor a term involving sectoral capital stocks. The correct regression yields a negative house price coefficient, as predicted by the model's equilibrium conditions. ${ }^{34}$ Thus we conclude that caution should be taken in using previous empirical work to assess the relative importance of demand versus supply-side shocks in the market for new housing.

\footnotetext{
${ }^{34}$ The correct equilibrium relation between residential investment, house prices and the interest rate is given by$$
(1-\phi) \log x_{d t}=\kappa+\log r_{t}-\log p_{h t}+\log \left(\sum_{i \in\{b, m, s\}} \frac{k_{i t}}{\theta_{i}}-\frac{k_{m t}}{M_{c} \theta_{m}}\right)
$$

where $\kappa$ is a constant equal to $\log \left(M_{c} /\left((1-\phi)\left(M_{c}-M_{d}\right)\right)\right.$. Regressions omitting the last term suffer from omitted-variable bias.
} 


\section{Conclusion}

This paper investigates the ability of a multi-sector growth model to replicate three facts: residential investment is more than twice as volatile as business investment; consumption, residential and non-residential investment co-move positively; and residential investment leads the business cycle whereas non-residential investment lags. We find that the model can account for two of these three facts, and isolate the features of the production technologies that account for these successes.

The high volatility of residential investment may be attributed to residential investment being constructive-intensive, and to the fact the residential structures depreciate very slowly. Being construction-intensive is important for volatility, both because construction-sector productivity is highly volatile and also because construction is laborintensive, so that construction output can be increased relatively efficiently without waiting for additional capital to become available. The fact that residential structures depreciate very slowly is important, because this increases the incentive to concentrate production of new structures in periods of high relative productivity. On the other hand, the fact that newly-available land is an input for producing new housing effectively works as an adjustment cost and tends to reduce residential investment volatility.

We have discussed a range of factors that have large effects on the correlation between different types of investment. For example, more correlated shocks help, and in the model developed here, the correlation of shocks is magnified at the final goods level, since both final goods sectors use all three intermediate inputs. To generate co-movement, it is also important that neither type of investment is too volatile. For example, consider an increase in productivity that makes non-residential investment relatively cheap. The smaller the subsequent rise in non-residential investment, the more output is available to increase residential investment. We find that the more important is land and the more persistent are shocks, the less volatile is investment and the stronger is co-movement. ${ }^{35}$

One failure of the model is that it does not reproduce the fact that residential investment leads GDP. In particular, in the data $\operatorname{corr}\left(R E S I_{t-1}, G D P_{t}\right)>\operatorname{corr}\left(R E S I_{t}, G D P_{t}\right)$ while in the model the strongest correlation is the contemporaneous one. We can claim some limited success, however, in that we reproduce the fact that the correla-

\footnotetext{
${ }^{35}$ In results not reported, we verified that introducing a convex adjustment cost for non-residential investment also increases investment co-movement.
} 
tion at a one period lead is greater than at a one period lag: $\operatorname{corr}\left(R E S I_{t-1}, G D P_{t}\right)>$ $\operatorname{corr}\left(R E S I_{t+1}, G D P_{t}\right)$. Part of the intuition for this result is that it is less important to accumulate non-residential capital prior to building new residential structures, since residential investment is relatively construction-intensive and therefore relatively laborintensive. ${ }^{36}$

Our model incorporates intermediate industries because this production structure allows us to identify productivity shocks in the data. The model replicates the empirical ordering of hours and output volatility across industries, and also implies that output and hours co-move across industries, as in the data. An important part of the calibration procedure involves using input-output data to pin down the relative importance of different intermediate inputs in various components of final expenditure. Our choices regarding the identities of intermediate and final-goods sectors in the model were guided by our focus on understanding the dynamics of residential investment. However, using the same calibration methodology it would be relatively straightforward to consider a finer disaggregation of the components of final expenditure, or to increase the number of intermediate sectors. For example, one could use the input mix estimates in table 6 to introduce an explicit non-residential investment sector.

The paper leaves several open issues for exploration. First, what can account for the strong lead of residential investment over the cycle? ${ }^{37}$ Second, although the model can account for the upward trend in the relative price of housing over the past thirty years, it does poorly in accounting for swings in house prices such as the run up in house prices that occurred in the late 1970's. The presence of land as a fixed factor in new home production in our model means that demand-side shocks will impact prices. Examples of such shocks include the demographics of the baby boom and bust, or changes through time in the effective size of the tax advantage conferred by mortgage interest deductibility. ${ }^{38}$ We plan to explore the role of demand shocks in future work.

\footnotetext{
${ }^{36}$ When all final goods are produced according to the same technology (and are therefore equally labor-intensive) it is non-residential investment rather than residential investment that weakly leads the cycle (compare columns $C$ and $D$ in table 10).

${ }^{37}$ Two recent working papers to address this issues are Peterson 2003 and Fisher 2001. Peterson argues that transactions costs coupled with uninsurable idiosyncratic earnings shocks whose variance is counter-cyclical can help account for the leading behavior of housing investment. In an economy with home production Fisher shows that household investment will lead non-residential investment if household capital is sufficiently useful in market production.

${ }^{38}$ See Poterba 1991 for some evidence on the importance of land prices and for a review of alternative
} 


\section{References}

[1] Baxter, M., 1996, "Are Consumer Durables Important for Business Cycles?", Review of Economics and Statistics 78 (1), 147-155.

[2] Benhabib, J., R. Rogerson, and R. Wright, 1991, "Homework in Macroeconomics: Household Production and Aggregate Fluctuations", Journal of Political Economy 99, 1166-1187.

[3] Boldrin, M., L. Christiano, and J. Fisher, 2001, "Habit Persistence, Asset Returns and the Business Cycle", American Economic Review 91 (1), 149-166.

[4] Chang, Y., 2000, "Comovement, Excess Volatility and Home Production", Journal of Monetary Economics 46, 385-396.

[5] Cooley, T. and E. Prescott, 1995, "Economic Growth and Business Cycles", in T. Cooley ed., Frontiers of Business Cycle Research, Princeton University Press, Princeton, 1-38.

[6] Diaz-Gimenez, J., E. Prescott, T. Fitzgerald, and F. Alvarez, "Banking in Computable General Equilibrium Economies", Research Department Staff Report 153, Federal Reserve Bank of Minneapolis.

[7] Domeij, D. and J. Heathcote, 2003, "On the Distributional Effects of Reducing Capital Taxes", International Economic Review, forthcoming.

[8] Edge, R., 2000, "The Effect of Monetary Policy on Residential and Structures Investment under Differential Project Planning and Completion Times", International Finance Discussion Paper Number 671, Board of Governors of the Federal Reserve System.

[9] Fernandez-Villaverde, J. and D. Krueger, 2002, "Consumption and Saving over the Life-Cycle: How Important are Consumer Durables?", in Proceedings of the 2002 North American Summer Meetings of the Econometric Society: Macroeconomic Theory, http://www.dklevine.com/proceedings/economic-theory.html.

theories of house prices. 
[10] Fisher, J., 1997, "Relative Prices, Complementarities and Comovement among Components of Aggregate Expenditures", Journal of Monetary Economics 39 (3), 449-474.

[11] Fisher, J. 2001, "Heterogeneous Investment Dynamics", working paper, Federal Reserve Bank of Chicago.

[12] Gervais, M., 2002, "Housing Taxation and Capital Accumulation", Journal of Monetary Economics, 49 (7), 1461-1489.

[13] Gomme, P., F. Kydland, and P. Rupert, 2001, "Home Production Meets Time to Build", Journal of Political Economy 109 (5), 1115-1131.

[14] Greenwood, J. and Z. Hercowitz, 1991, "The Allocation of Capital and Time over the Business Cycle", Journal of Political Economy 99, 1188-1214.

[15] Greenwood, J., R. Rogerson, and R. Wright, 1995, "Household Production in Real Business Cycle Theory", in T. Cooley ed., Frontiers of Business Cycle Research, Princeton University Press, Princeton, 157-174.

[16] Hansen, G. and E. Prescott, 1993, "Did Technology Shocks Cause the 1990-1991 Recession?", American Economic Review 83 (2), 280-286.

[17] Hornstein, A. and J. Praschnik, 1997, "Intermediate Inputs and Sectoral Comovement in the Business Cycle", Journal of Monetary Economics 40, 573-595.

[18] Kearl, J., 1979, "Inflation, Mortgage, and Housing", Journal of Political Economy 87 (5), 1115-1138.

[19] Klein, P., 2000, "Using the Generalized Schur Form to Solve a Multi-variate Linear Rational Expectations Model", Journal of Economic Dynamics and Control 24 (10), 1405-1423.

[20] Krusell, P. and A. Smith, 1998, "Income and Wealth Heterogeneity in the Macroeconomy", Journal of Political Economy 106, 867-896.

[21] Long, J.B. and C.I. Plosser, 1983, "Real Business Cycles", Journal of Political Economy 91 (1), 39-69. 
[22] Ortalo-Magne, F. and S. Rady, 2001, "Housing Market Dynamics: On the Contribution of Income Shocks and Credit Constraints", CEPR Working Paper 3015.

[23] Peterson, B., 2003, "Aggregate Uncertainty, Individual Uncertainty and the Housing Market", working paper, Indiana University.

[24] Pieper, P.E., 1990, "The Measurement of Construction Prices: Retrospect and Prospect", in E.R. Berndt and J.E. Triplett eds. Fifty Years of Economic Measurement: The Jubilee of the Conference on Research in Income and Wealth, University of Chicago Press.

[25] Platania, J. and D. Schlagenhauf, 2000, "Housing and Asset Holding in a Dynamic General Equilibrium Model", working paper, Florida State University.

[26] Poterba, J., 1984, "Tax Subsidies to Owner-occupied Housing: An Asset Market Approach", Quarterly Journal of Economics 99, 729-752.

[27] Poterba, J., 1991, "House Price Dynamics: The Role of Tax Policy and Demography", Brookings Papers on Economic Activity 2:1991, 143-203.

[28] Rios-Rull, J.V., 1994, "On the Quantitative Importance of Market Completeness", Journal of Monetary Economics 34, 462-496.

[29] Storesletten, K., 1993, "Residential Investment over the Business Cycle", working paper, Institute for International Economic Studies, Stockholm University.

[30] Topel, R. and S. Rosen, 1988, "Housing Investment in the United States", Journal of Political Economy 96 (4), 718-740. 


\section{Data Sources Appendix}

\begin{tabular}{|c|c|c|}
\hline Variable $^{1}$ & $\begin{array}{c}\text { Data } \\
\text { Source }^{2}\end{array}$ & Computation \\
\hline GDP & NIPA & Chain-weighted GDP (Tables 1.1 line 1 and 7.1 line 2) \\
\hline PCE & NIPA & $\begin{array}{l}\text { Chain-weighted personal consumption expenditures (Tables } 1.1 \text { line } 2 \text { and } 7.1 \\
\text { line 6) }\end{array}$ \\
\hline Non-RESI & NIPA & $\begin{array}{l}\text { Chain-weighted aggregate of gross private domestic investment (Tables } 1.1 \text { line } \\
7 \text { and } 7.1 \text { line 22), fixed federal non-defense investment (Tables } 3.7 \text { line } 24 \text { and } \\
7.11 \text { line 24), and state and local investment (Tables } 3.7 \text { line } 35 \text { and } 7.11 \text { line } 35 \text { ), } \\
\text { less residential gross private domestic investment (Tables } 1.1 \text { line } 11 \text { and } 7.1 \text { line } \\
\text { 42) }\end{array}$ \\
\hline RESI & NIPA & $\begin{array}{l}\text { Chain-weighted residential gross private domestic investment (Tables } 1.1 \text { line } 11 \\
\text { and } 7.1 \text { line 42) }\end{array}$ \\
\hline Government & NIPA & Nominal government consumption expenditures and gross investment (Table 1.1 \\
\hline $\begin{array}{l}\text { consumption } \\
\text { (nominal) }\end{array}$ & & $\begin{array}{l}\text { line 20) less nominal federal government fixed non-defense investment (Table } \\
3.7 \text { line } 24 \text { ) less nominal state and local fixed investment (Table } 3.7 \text { line } 35 \text { ) }\end{array}$ \\
\hline Total Labor & NIPA & $\begin{array}{l}\text { Hours worked by full-time and part-time employees, private industries (Tables } \\
6.9 \mathrm{~B} \text { and } 6.9 \mathrm{C} \text { line } 3 \text { ) }\end{array}$ \\
\hline House Prices & $\begin{array}{l}\text { CMHPI, } \\
\text { NIPA }\end{array}$ & $\begin{array}{l}\text { Conventional mortgage home price index (CMHPI, USA) divided by price index } \\
\text { for personal consumption expenditures (NIPA, Table } 7.1 \text { line } 7 \text { ) }\end{array}$ \\
\hline $\begin{array}{l}\text { Construction } \\
\text { output }\end{array}$ & GPO & $\begin{array}{l}\text { For } 1977-2001 \text { : Nominal construction output in } 1996 \text { (the variable "GPC") } \\
\text { times the quantity index for GDP for the Construction industry, the variable } \\
\text { "GPCWI"3 }\end{array}$ \\
\hline $\begin{array}{l}\text { Construction } \\
\text { hours }\end{array}$ & NIPA & $\begin{array}{l}\text { Hours worked by full-time and part-time employees, Construction (Tables 6.9B } \\
\text { and } 6.9 \mathrm{C} \text { line } 8 \text { ) }\end{array}$ \\
\hline $\begin{array}{l}\text { Construction } \\
\text { capital }\end{array}$ & Assets & Chain-weighted fixed assets for Construction (Tables 3.1ES and 3.2ES line 12) \\
\hline $\begin{array}{l}\text { Manufac- } \\
\text { turing output }\end{array}$ & GPO & $\begin{array}{l}\text { For } 1977-2001 \text { : Sum of real GDP by industry in millions of chained dollars for } \\
\text { Agriculture, Forestry, and Fishing, Mining (AFF), and Manufacturing. To create } \\
\text { real GDP for each industry, nominal output in } 1996 \text { (GPC) is multiplied by the } \\
\text { appropriate quantity index (GPCWI) }\end{array}$ \\
\hline $\begin{array}{l}\text { Manufac- } \\
\text { turing hours }\end{array}$ & NIPA & $\begin{array}{l}\text { From Tables 6.9B and 6.9C: Sum of hours worked by full-time and part-time } \\
\text { employees for AFF (line 4), Mining (line 7), and Manufacturing (line 9) }\end{array}$ \\
\hline $\begin{array}{l}\text { Manufac- } \\
\text { turing capital }\end{array}$ & Assets & $\begin{array}{l}\text { From Tables } 3.1 \mathrm{ES} \text { and 3.2ES: The sum of chain-weighted fixed assets for AFF } \\
\text { (line 2), Mining (line 7), and Manufacturing (line 13) }\end{array}$ \\
\hline $\begin{array}{l}\text { Services } \\
\text { output }\end{array}$ & GPO & $\begin{array}{l}\text { For } 1977-2001 \text { : Sum of real GDP by industry in millions of chained dollars for } \\
\text { Transportation and Public Utilities (TPU), Wholesale Trade, Retail Trade, and } \\
\text { Services. To create real GDP for each industry, nominal output in } 1996 \text { (GPC) is } \\
\text { multiplied by the appropriate quantity index (GPCWI) }\end{array}$ \\
\hline $\begin{array}{l}\text { Services } \\
\text { hours }\end{array}$ & NIPA & $\begin{array}{l}\text { From Tables 6.9B and 6.9C: Sum of hours worked by full-time and part-time } \\
\text { employees for TPU (line 12), Wholesale Trade (line 16), Retail Trade (line 17), } \\
\text { and Services (line 19) }\end{array}$ \\
\hline $\begin{array}{l}\text { Services } \\
\text { capital }\end{array}$ & Assets & $\begin{array}{l}\text { From Tables 3.1ES and 3.2ES: Sum of chain-weighted fixed assets for TPU (line } \\
\text { 37), Wholesale Trade (line 53), Retail Trade (line 54), and Services (line 68) }\end{array}$ \\
\hline
\end{tabular}

\footnotetext{
${ }^{1}$ Except for government consumption, house prices, and all the hours series, the variables in this table are real chain-weighted variables with a base year of 1996.

${ }^{2}$ NIPA = National Income and Product Accounts Tables, Bureau of Economic Analysis; CMHPI = Conventional Mortgage Home Price Index, Freddie Mac; GPO Gross Domestic Product by Industry Tables, Bureau of Economic Analysis; Assets = Fixed Assets Tables, Bureau of Economic Analysis.

${ }^{3}$ The BEA is currently publishing real output by industry only back to 1977 . To construct the $1947-76$ estimates of real output by industry for each industry, we refer to published tables in the Survey of Current Business for April 1967 (1947-63), April 1968 (1964), April 1969 (1965), April 1970 (1966), April 1971 (1967-1969), July 1973 (1970-1971), July 1976 (1972), July 1977 (1973-74), July 1978 (1975), and July 1979 (1976).
} 
Table 1: Growth Rates on Balanced Growth Path (growth rates gross, variables per-capita)

$$
\begin{array}{cc}
\mathrm{n}_{\mathrm{b}}, \mathrm{n}_{\mathrm{m}}, \mathrm{n}_{\mathrm{s}}, \mathrm{n}, \mathrm{r} & 1 \\
\mathrm{k}_{\mathrm{b}}, \mathrm{k}_{\mathrm{m}}, \mathrm{k}_{\mathrm{s}}, \mathrm{k}, \mathrm{c}, \mathrm{i}_{\mathrm{k}}, \mathrm{g}, \mathrm{y}_{\mathrm{c}}, \mathrm{w} & g_{k}=\left[g_{z b}^{B_{c}\left(1-\theta_{b}\right)} g_{z m}^{M_{c}\left(1-\theta_{m}\right)} g_{z s}^{S_{c}\left(1-\theta_{s}\right)}\right] \frac{1}{1-B_{c} \theta_{b}-M_{c} \theta_{m}-S_{c} \theta_{s}} \\
\mathrm{~b}_{\mathrm{c}}, \mathrm{b}_{\mathrm{h}}, \mathrm{x}_{\mathrm{b}} & g_{b}=g_{k}^{\theta_{b}} g_{z b}^{1-\theta_{b}} \\
\mathrm{~m}_{\mathrm{c}}, \mathrm{m}_{\mathrm{h}}, \mathrm{x}_{\mathrm{m}} & g_{m}=g_{k}^{\theta_{m}} g_{z m}^{1-\theta_{m}} \\
\mathrm{~s}_{\mathrm{c}}, \mathrm{s}_{\mathrm{h}}, \mathrm{x}_{\mathrm{s}} & g_{s}=g_{k}^{\theta_{s}} g_{z s}^{1-\theta_{s}} \\
\mathrm{x}_{\mathrm{d}} & g_{d}=g_{b}^{B_{h}} g_{m}^{M_{h}} g_{s}^{S_{h}} \\
\mathrm{x}_{1} & g_{l}=\eta^{-1} \\
\mathrm{y}_{\mathrm{h}}, \mathrm{h} & g_{h}=g_{l}^{\phi} g_{d}^{1-\phi} \\
\mathrm{p}_{\mathrm{h}} \mathrm{y}_{\mathrm{h}}, \mathrm{p}_{\mathrm{d}} \mathrm{x}_{\mathrm{d}}, \mathrm{p}_{\mathrm{l}} \mathrm{x}_{\mathrm{l}}, \mathrm{p}_{\mathrm{b}} \mathrm{x}_{\mathrm{b}}, \mathrm{p}_{\mathrm{m}} \mathrm{x}_{\mathrm{m}}, \mathrm{p}_{\mathrm{s}} \mathrm{x}_{\mathrm{s}} & g_{k}
\end{array}
$$

Table 2: Tax Rates, Depreciation Rates, Adjustment Costs, Preference Parameters

Davis Heathcote

Tax rate on capital income: $\tau_{\mathrm{k}}$

Tax rate on labor income: $\tau_{\mathrm{n}}$

Govt. cons. to GDP

Transfers to GDP

Depreciation rate for capital: $\delta_{\mathrm{k}}$

Depreciation rate for res. structures: $\delta_{\mathrm{s}}$

Land's share in new housing: $\varphi$

Population growth rate: $\eta$

Discount factor: $\beta$

Risk aversion: $\sigma$

Consumption's share in utility: $\mu_{\mathrm{c}}$

Housing's share in utility: $\mu_{\mathrm{h}}$

Leisure's share in utility: $1-\mu_{\mathrm{c}}-\mu_{\mathrm{h}}$
0.3788

0.2892

$0.179 *^{4}$

$0.076^{*}$

$0.0557^{*}$

$0.0157^{*}$

0.106

$1.0167 *$

0.9512

$2.00 *$

0.3139

0.0444

0.6417
Grenwood Hercowitz (GH)

0.50

0.25

0.0

0.078

0.078

0.0

0.96

1.00

0.2600

0.0962

0.6438

\footnotetext{
${ }^{4}$ Starred parameter vales are chosen independently of the model.
} 


\begin{tabular}{lcccc}
\hline Table 3: Production Technologies & & & & \\
\hline & Con. & Man. & Ser. & $G H$ \\
Input shares in cons/inv production $\mathrm{B}_{\mathrm{c},}, \mathrm{M}_{\mathrm{c}}, \mathrm{S}_{\mathrm{c}}$ & 0.0307 & 0.2696 & 0.6997 & \\
Input shares in res. structures $\mathrm{B}_{\mathrm{d},}, \mathrm{M}_{\mathrm{d}}, \mathrm{S}_{\mathrm{d}}$ & 0.4697 & 0.2382 & 0.2921 & \\
Capital's share by sector $\theta_{\mathrm{b}}, \theta_{\mathrm{m},}, \theta_{\mathrm{s}}$ & 0.132 & 0.309 & 0.237 & 0.30 \\
Trend productivity growth $(\%) \mathrm{g}_{\mathrm{zb}}, \mathrm{g}_{\mathrm{zm}}, \mathrm{g}_{\mathrm{zs}}$ & -0.27 & 2.85 & 1.65 & 1.00 \\
$\quad$ Autocorrelation coefficient & & see table 4 & & $\rho=1.0$ \\
Std. dev. innovations to logged productivity & & see table 4 & & 0.022 \\
\end{tabular}

\section{Table 4: Estimation of Exogenous Shock Process}

System estimated: $\widetilde{z}_{t+1}=B \widetilde{z}_{t}+\varepsilon_{t+1}$

where $\widetilde{z}_{t}=\left(\begin{array}{l}\log \widetilde{z}_{b t} \\ \log \widetilde{z}_{m t} \\ \log \widetilde{z}_{s t}\end{array}\right), \varepsilon_{t}=\left(\begin{array}{c}\varepsilon_{b t} \\ \varepsilon_{m t} \\ \varepsilon_{s t}\end{array}\right)$ and $\varepsilon_{t} \sim N(0, V) .^{5}$

Autoregressive coefficients in matrix $B$

(Seemingly unrelated regression estimation method: standard errors in parentheses)

$\begin{array}{cccc} & \log \widetilde{\mathrm{z}}_{\mathrm{b}, \mathrm{t}+1} & \log \widetilde{\mathrm{z}}_{\mathrm{m}, \mathrm{t}+1} & \log \widetilde{\mathrm{z}}_{\mathrm{s}, \mathrm{t}+1} \\ \log \widetilde{\mathrm{z}}_{\mathrm{bt}} & 0.707 & -0.006 & 0.003 \\ & (0.089) & (0.078) & (0.038) \\ \log \widetilde{\mathrm{z}}_{\mathrm{mt}} & 0.010 & 0.871 & 0.028 \\ & (0.083) & (0.073) & (0.036) \\ \log \widetilde{\mathrm{z}}_{\mathrm{st}} & -0.093 & -0.150 & 0.919 \\ & (0.098) & (0.087) & (0.042) \\ R^{2} & 0.551 & 0.729 & 0.903 \\ & \text { Correlations of innovations }\end{array}$

\begin{tabular}{cccccc} 
& $\varepsilon_{\mathrm{b}}$ & $\varepsilon_{\mathrm{m}}$ & $\varepsilon_{\mathrm{s}}$ & & \\
$\varepsilon_{\mathrm{b}}$ & 1 & 0.089 & 0.306 & $\varepsilon_{\mathrm{b}}$ & 0.041 \\
$\varepsilon_{\mathrm{m}}$ & & 1 & 0.578 & $\varepsilon_{\mathrm{m}}$ & 0.036 \\
$\varepsilon_{\mathrm{s}}$ & & & 1 & $\varepsilon_{\mathrm{s}}$ & 0.018 \\
\hline
\end{tabular}

\footnotetext{
${ }^{5}$ All variables are linearly detrended prior to estimating this system.
} 
Table 5: Decomposition of Final Expenditure into Final Sales From Industries (\%)

(based on 1992 IO-Use Table)

\begin{tabular}{lccccc}
\hline & PCE & BFI + RESI & RESI $^{6}$ & BFI & $\mathrm{G}^{7}$ \\
\hline Construction & 0.0 & 43.9 & 100.0 & 22.6 & 33.6 \\
Manufacturing & 23.3 & 41.3 & 0.0 & 56.9 & 44.2 \\
Services & 76.7 & 14.8 & 0.0 & 20.5 & 22.2 \\
\hline
\end{tabular}

Table 6: Decomposition of Final Expenditure into Value Added by Industry (\%)

\begin{tabular}{lccccc}
\hline & PCE & BFI + RESI & RESI & BFI & $\begin{array}{c}\text { PCE + BFI + } \\
\text { GOVI }^{8}\end{array}$ \\
\hline Construction & 1.4 & 21.3 & 47.0 & 11.6 & 3.1 \\
Manufacturing & 23.0 & 40.6 & 23.8 & 46.9 & 27.0 \\
Services & 75.7 & 38.1 & 29.2 & 41.5 & 70.0 \\
\hline
\end{tabular}

Table 7: Properties of Steady State: Ratios to GDP \%

$\begin{array}{rcc} & \text { Data }(1948-2001) & \text { Model } \\ \text { Capital stock }(\mathrm{K}) & 152 & 152 \\ \text { Residential structures stock }\left(\mathrm{P}_{\mathrm{d}} \mathrm{X}\right) & 100 & 100 \\ \text { Private consumption }(\mathrm{PCE}) & 63.8 & 63.9 \\ \text { Government consumption }(\mathrm{G}) & 17.9 & 17.9 \\ \text { Non-residential inv }(\text { non-RESI) } & 13.5 & 13.9 \\ \text { Residential inv }\left(\mathrm{P}_{\mathrm{d}} \times \mathrm{RESI}\right) & 4.7 & 4.4 \\ \text { Construction }\left(\mathrm{P}_{\mathrm{b}} \times \mathrm{Y}_{\mathrm{b}}\right) & 5.2^{9} & 4.8 \\ \text { Manufacturing }\left(\mathrm{P}_{\mathrm{m}} \times \mathrm{Y}_{\mathrm{m}}\right) & 32.8 & 24.7 \\ \text { Services }\left(\mathrm{P}_{\mathrm{s}} \times \mathrm{Y}_{\mathrm{s}}\right) & 61.5 & 70.6 \\ \text { Real after tax interest rate }(\%) & & 6.0\end{array}$

\footnotetext{
${ }^{6}$ We attribute all $\$ 225.5$ billion of residential investment in 1992 to sales from the construction industry, since the first I/O use table does not have a 'residential investment' column. We defend this choice in the data appendix.

${ }^{7} \mathrm{G}$ is government expenditure, which includes government consumption and government investment expenditures.

${ }^{8}$ GOVI is government investment. We assume that the value-added composition of government investment by intermediate industry is the same as business fixed investment.

${ }^{9}$ The shares of construction, manufacturing and services do not add to exactly one, since the product approach to computing GDP does not give exactly the same answer as the expenditure approach. In both model and data, imputed rental income from owner-occupied housing is attributed to the service sector.
} 


\begin{tabular}{|c|c|c|c|c|c|c|c|}
\hline \multicolumn{8}{|c|}{ Table 8: Business Cycle Properties ${ }^{10}$} \\
\hline & & \multicolumn{3}{|c|}{ Data (1948-2001) } & \multicolumn{3}{|c|}{ Model } \\
\hline$\%$ Standard Deviations & GDP & \multicolumn{3}{|c|}{2.26} & \multicolumn{3}{|c|}{1.73} \\
\hline \multirow[t]{5}{*}{ (rel. to GDP) } & PCE & \multicolumn{3}{|c|}{0.78} & \multicolumn{3}{|c|}{0.48} \\
\hline & Labor $(\mathrm{N})$ & \multicolumn{3}{|c|}{1.01} & \multicolumn{3}{|c|}{0.41} \\
\hline & Non-RESI & \multicolumn{3}{|c|}{2.30} & \multicolumn{3}{|c|}{3.21} \\
\hline & RESI & \multicolumn{3}{|c|}{5.04} & \multicolumn{3}{|c|}{6.12} \\
\hline & House prices $\left(\mathrm{P}_{\mathrm{h}}\right)$ & \multicolumn{3}{|c|}{$1.37(1970-2001)$} & \multicolumn{3}{|c|}{0.40} \\
\hline Const & truction output $\left(\mathrm{Y}_{\mathrm{b}}\right)$ & \multicolumn{3}{|c|}{2.74} & \multicolumn{3}{|c|}{4.02} \\
\hline Manufac & cturing output $\left(\mathrm{Y}_{\mathrm{m}}\right)$ & \multicolumn{3}{|c|}{1.85} & \multicolumn{3}{|c|}{1.58} \\
\hline & Services output $\left(\mathrm{Y}_{\mathrm{s}}\right)$ & \multicolumn{3}{|c|}{0.85} & \multicolumn{3}{|c|}{0.99} \\
\hline Cons & struction hours $\left(\mathrm{N}_{\mathrm{b}}\right)$ & \multicolumn{3}{|c|}{2.32} & \multicolumn{3}{|c|}{2.15} \\
\hline Manufa & acturing hours $\left(\mathrm{N}_{\mathrm{m}}\right)$ & \multicolumn{3}{|c|}{1.53} & \multicolumn{3}{|c|}{0.39} \\
\hline & Services hours $\left(\mathrm{N}_{\mathrm{s}}\right)$ & \multicolumn{3}{|c|}{0.66} & \multicolumn{3}{|c|}{0.37} \\
\hline \multirow[t]{9}{*}{ Correlations } & PCE, GDP & \multicolumn{3}{|c|}{0.80} & \multicolumn{3}{|c|}{0.95} \\
\hline & $\mathrm{P}_{\mathrm{h}}, \mathrm{GDP}$ & \multicolumn{3}{|c|}{$0.65(1970-2001)$} & & 0.65 & \\
\hline & PCE, non-RESI & & 0.61 & & & 0.91 & \\
\hline & PCE, RESI & & 0.66 & & & 0.26 & \\
\hline & non-RESI, RESI & & 0.25 & & & 0.15 & \\
\hline & $\mathrm{P}_{\mathrm{h}}, \mathrm{RESI}$ & & $(1970-$ & $01)$ & & -0.20 & \\
\hline & $\mathrm{N}_{\mathrm{b}}, \mathrm{N}_{\mathrm{m}}$ & & 0.75 & & & 0.48 & \\
\hline & $\mathrm{N}_{\mathrm{b}}, \mathrm{N}_{\mathrm{s}}$ & & 0.86 & & & 0.23 & \\
\hline & $\mathrm{N}_{\mathrm{m}}, \mathrm{N}_{\mathrm{s}}$ & & 0.79 & & & 0.96 & \\
\hline Lead-lag correlations & & $\mathrm{i}=1$ & $\mathrm{i}=0$ & $\mathrm{i}=-1$ & $\mathrm{i}=1$ & $\mathrm{i}=0$ & $i=-1$ \\
\hline & non-RESI ${ }_{t-1}, G D P_{t}$ & 0.25 & 0.75 & 0.48 & 0.45 & 0.94 & 0.33 \\
\hline & $\mathrm{RESI}_{\mathrm{t}-\mathrm{i}}, \mathrm{GDP}_{\mathrm{t}}$ & 0.52 & 0.47 & -0.22 & 0.19 & 0.44 & 0.14 \\
\hline & non-RESI $_{t-i}, \operatorname{RESI}_{t}$ & -0.37 & 0.25 & 0.53 & 0.07 & 0.15 & 0.08 \\
\hline
\end{tabular}

\footnotetext{
${ }^{10}$ Statistics are averages over 500 simulations, each of length 54 periods, the length of our data sample. Prior to computing statistics all variables are (i) transformed from the stationary representation used in the solution procedure back into non-stationary representation incorporating trend growth, (ii) logged, and (iii) Hodrick-Prescott filtered with the smoothing parameter, $\lambda$, set to 100 .
} 
Table 9: Alternative Parameterizations

\begin{tabular}{ccc}
\hline $\begin{array}{c}\text { Model } \\
G H\end{array}$ & $\begin{array}{c}\text { Description } \\
\text { Greenwood and Hercowitz }\end{array}$ & $\begin{array}{c}\text { Selected parameter values } \\
\text { see tables } 2 \text { and } 3\end{array}$ \\
$A$ & $\begin{array}{c}\text { One sector model, housing in utility } \\
\text { (re-parameterized } G H)\end{array}$ & $\sigma=2, \rho=0.85, \sigma(\varepsilon)=0.022$ \\
& & $\delta_{\mathrm{k}}=\delta_{\mathrm{s}}=0.0557$ \\
& $\theta_{\mathrm{b}}=\theta_{\mathrm{m}}=\theta_{\mathrm{s}}=0.25$ \\
$B$ & $A+$ land & $\mathrm{B}_{\mathrm{d},}=\mathrm{B}_{\mathrm{c},}, \mathrm{M}_{\mathrm{d},}=\mathrm{M}_{\mathrm{c},}, \mathrm{S}_{\mathrm{d},}=\mathrm{S}_{\mathrm{c}}$ \\
$C$ & $B+$ sector-specific shocks & $\varphi=0.106$ \\
$D$ & $C+$ two final goods technologies & see table 4 \\
$E$ & $D+$ sector-specific capital shares & $\theta_{\mathrm{b}}=0.132, \theta_{\mathrm{m}}=0.309, \theta_{\mathrm{s}}=0.237$ \\
$F$ (Benchmark) & $E+$ different depreciation rates & $\delta_{\mathrm{s}}=0.0157$ \\
\hline
\end{tabular}

\section{Table 10: Alternative Parameterizations: Business Cycle Properties}

\begin{tabular}{|c|c|c|c|c|c|c|c|c|}
\hline & Data & $G H$ & $A$ & $B$ & $C$ & $D$ & $E$ & $F$ \\
\hline GDP (\% std dev) & 2.26 & 1.37 & 1.93 & 1.88 & 1.69 & 1.69 & 1.67 & 1.73 \\
\hline \multicolumn{9}{|c|}{ Std. dev. relative to GDP } \\
\hline PCE & 0.78 & 0.60 & 0.39 & 0.39 & 0.42 & 0.44 & 0.45 & 0.48 \\
\hline $\mathrm{N}$ & 1.01 & 0.36 & 0.47 & 0.48 & 0.45 & 0.44 & 0.45 & 0.41 \\
\hline Non-RESI & 2.30 & 2.74 & 3.92 & 3.55 & 3.41 & 3.46 & 3.30 & 3.21 \\
\hline RESI & 5.04 & 2.08 & 2.86 & 1.22 & 1.22 & 4.25 & 5.10 & 6.12 \\
\hline $\mathrm{Y}_{\mathrm{b}}$ & 2.74 & 1.25 & 1.15 & 1.16 & 1.82 & 3.66 & 4.36 & 4.02 \\
\hline $\mathrm{Y}_{\mathrm{m}}$ & 1.85 & 1.25 & 1.15 & 1.16 & 1.80 & 1.79 & 1.65 & 1.58 \\
\hline $\mathrm{Y}_{\mathrm{s}}$ & 0.85 & 1.25 & 1.15 & 1.16 & 1.06 & 1.05 & 1.05 & 0.99 \\
\hline $\mathrm{P}_{\mathrm{h}}$ & 1.37 & 0.00 & 0.00 & 0.13 & 0.13 & 0.41 & 0.45 & 0.40 \\
\hline \multicolumn{9}{|l|}{ Correlations } \\
\hline Non-RESI, RESI & 0.25 & 0.88 & -0.10 & 0.73 & 0.75 & -0.07 & -0.07 & 0.15 \\
\hline $\mathrm{P}_{\mathrm{h}}, \mathrm{RESI}$ & 0.34 & - & - & 1.00 & 1.00 & -0.44 & -0.48 & -0.20 \\
\hline \multicolumn{9}{|c|}{ Lead-lag pattern: $\operatorname{corr}\left(x_{t-1}, G D P_{t}\right)-\operatorname{corr}\left(x_{t+1}, G D P_{t}\right)$} \\
\hline $\mathrm{x}=$ RESI. & 0.74 & -0.11 & -0.93 & -0.48 & -0.46 & 0.04 & 0.11 & 0.12 \\
\hline $\mathrm{x}=$ Non-RESI & -0.23 & 0.37 & 0.46 & 0.21 & 0.20 & 0.11 & 0.07 & 0.05 \\
\hline
\end{tabular}


Figure 1: GDP, Hours Worked, Private Consumption

and Non-residential Investment (mean model and data $=1$ )

$\log$ GDP

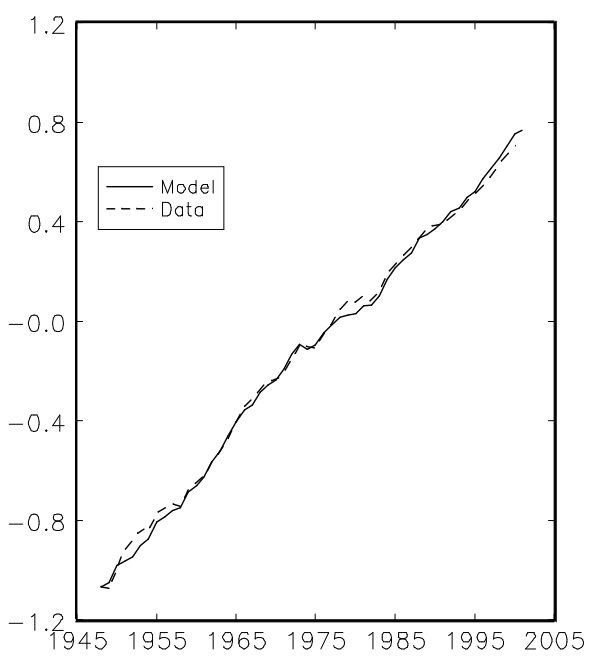

log Private Consumption

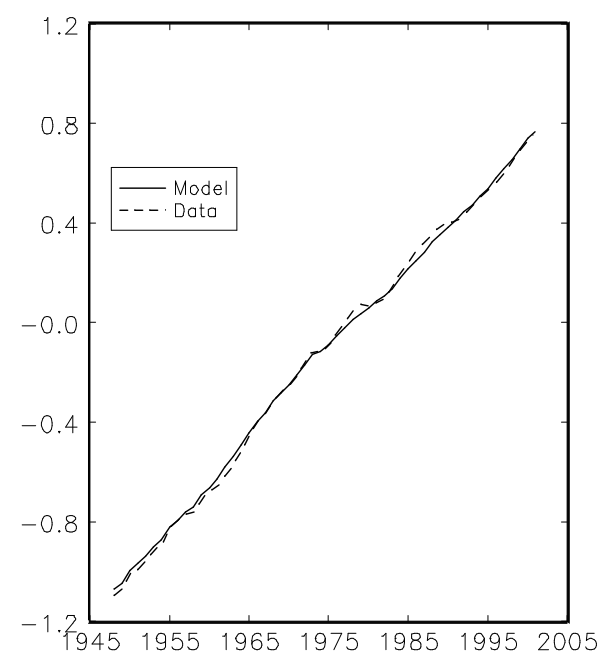

$\log$ Hours

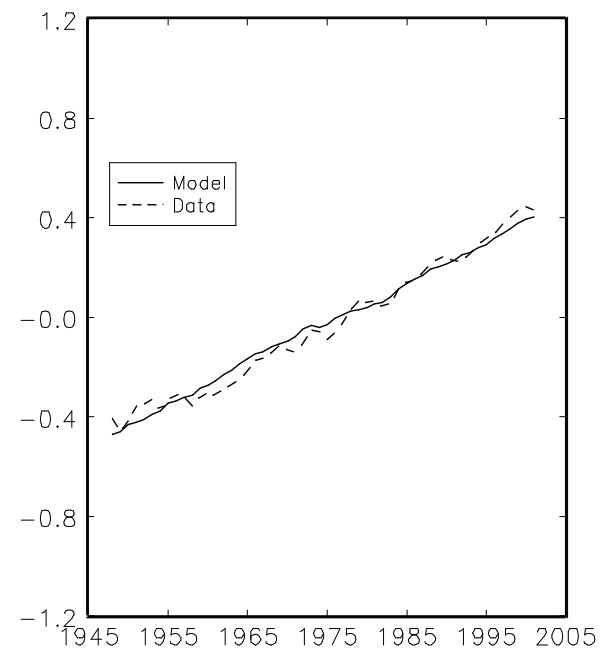

$\log$ Non-res. Inv.

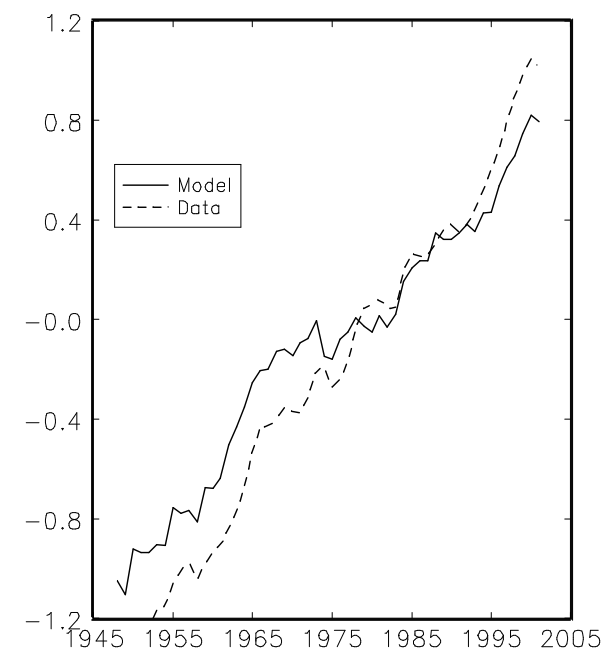


Figure 2: Residential Investment, House Prices, Construction and Manufacturing Output (mean model and data $=1$ )

$\log$ Residential Inv.

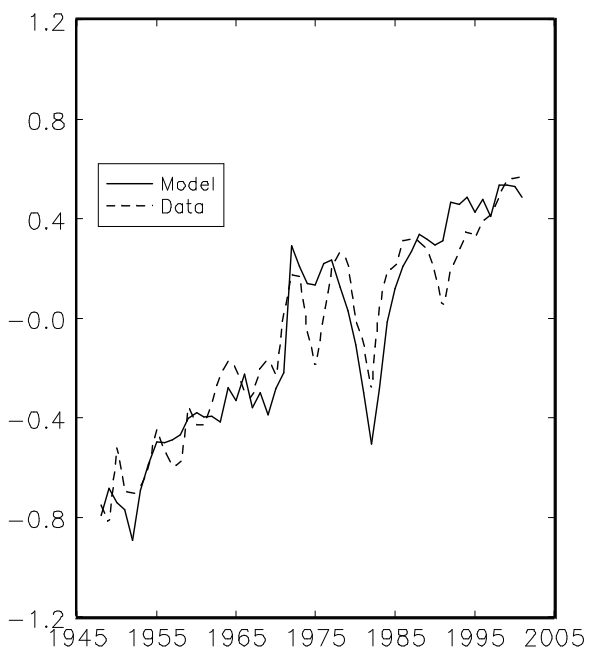

$\log$ Construction Output

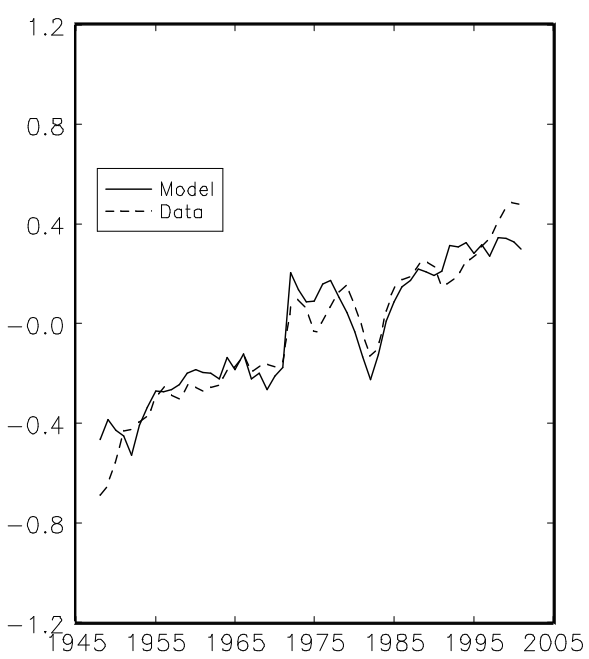

log Pr. Houses / Pr. Cons.

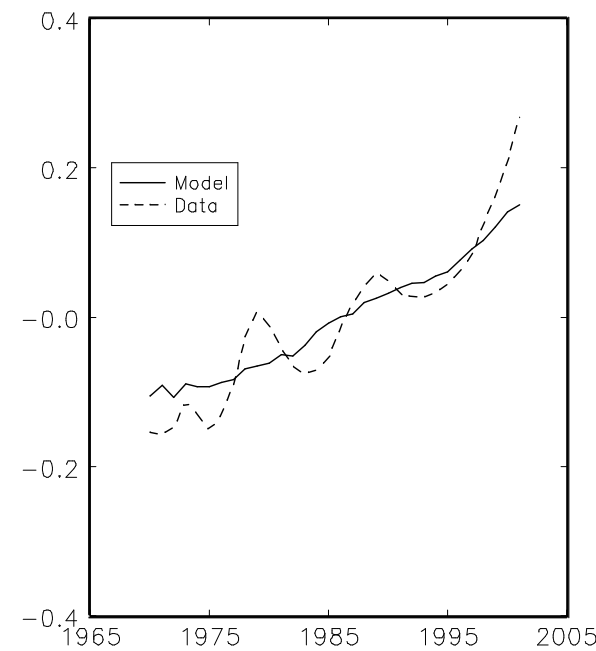

log Manufacturing Output

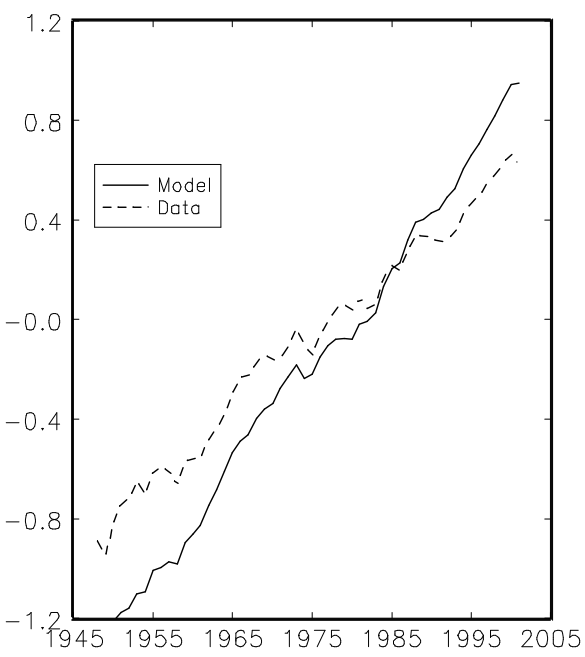


Figure 3: Percentage deviations from Hodrick Prescott trend

Gross Domestic Product

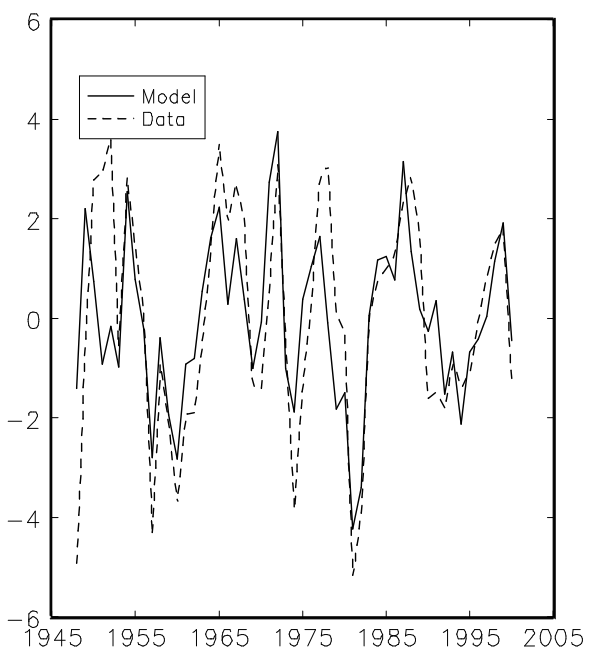

Non-res. Investment

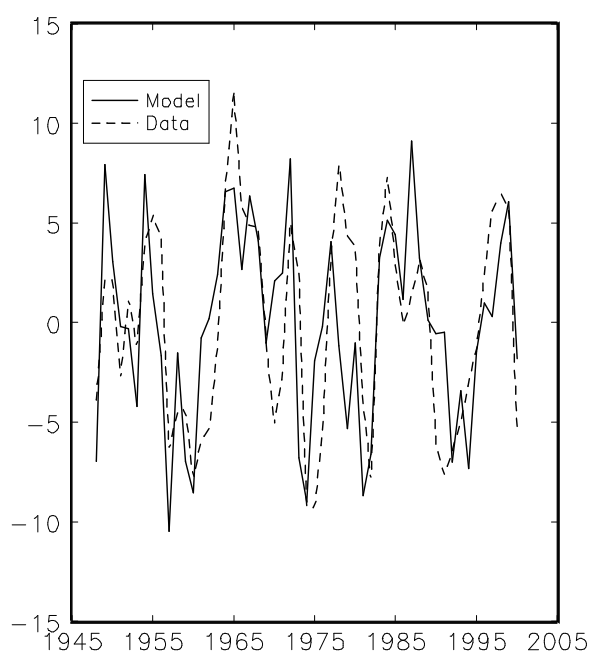

Private Consumption

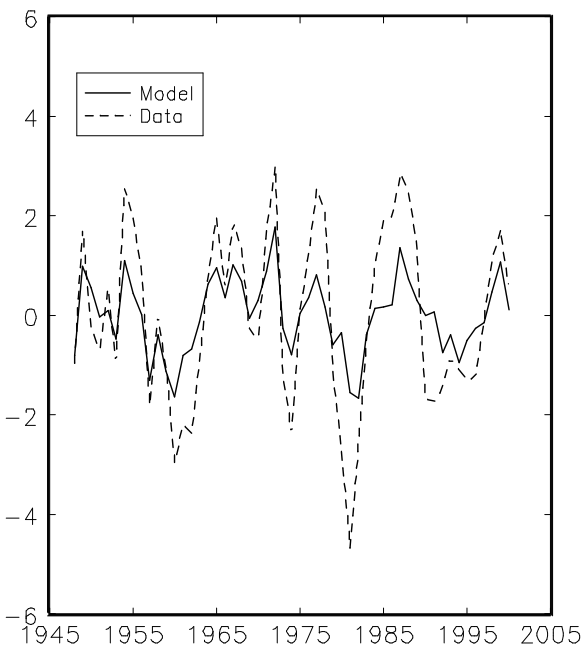

Residential Investment

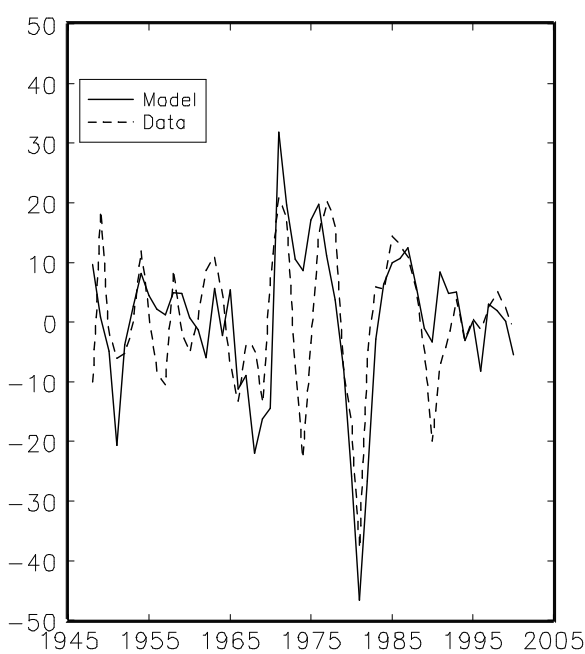

